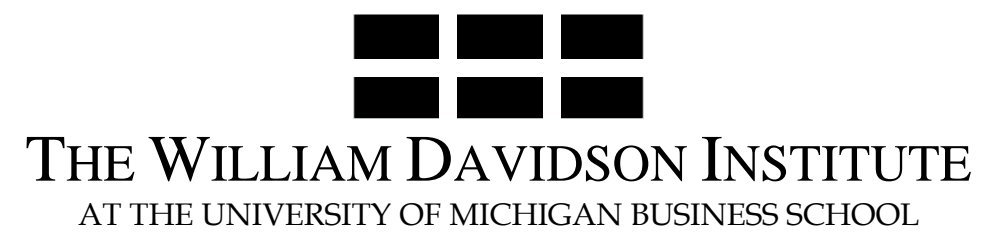

AT THE UNIVERSITY OF MICHIGAN BUSINESS SCHOOL

\title{
Bank Supervision Russian style: Rules versus Enforcement and Tacit Objectives
}

\author{
By: Sophie Claeys, Gleb Lanine and Koen Schoors
}

William Davidson Institute Working Paper Number 778

June 2005 


\title{
Bank Supervision Russian style: Rules versus Enforcement and Tacit Objectives*
}

\author{
Sophie Claeys ${ }^{a}$, Gleb Lanine ${ }^{a)}$ and Koen Schoors ${ }^{b) \dagger}$ \\ a) Department of Financial Economics, Ghent University, Belgium \\ b) CERISE, Ghent University, Belgium, \\ and WDI, University of Michigan Business School, US
}

May 2005

\footnotetext{
${ }^{*}$ The authors thank Claudia Buch, Björn Christensen, Jelena Hartsenko, Edward Kane, Alexei Karas, Bruno Merlevede, Rudi Vander Vennet, Ksenia Yudaeva, participants at the WP Forum of Ghent University, the seminar of ZEI, the SUERF Workshop in Kiel 2004, the IAES conference in Lisbon 2004, the EEA conference in Madrid 2004, the BOFIT/CEFIR workshop in Moscou 2005 for valuable comments and suggestions. Sophie Claeys acknowledges financial support from the Programme on Interuniversity Poles of Attraction of the Belgian Federal Office for Scientific, Technical and Cultural Affairs, contract No. P5/2.

${ }^{\dagger}$ Corresponding author: Koen Schoors, Department of Economics and Centre for Russian International Sociopolitical and Economic studies (CERISE), Ghent University, Hoveniersberg 24, B-9000 Ghent, Tel.: 32-9-264 34 78, Fax.: 32-9-264 35 99, e-mail: Koen.Schoors@UGent.be.
} 


\title{
Bank Supervision Russian style: Rules versus Enforcement and Tacit Objectives
}

\begin{abstract}
We focus on the conflict between two central bank objectives, namely individual bank stability and systemic stability. We study the licensing policy of the Central Bank of Russia (CBR) in 1999-2002. Banks in poorly banked regions, banks that are too big to be disciplined adequately and banks that are active on the interbank market enjoy protection from license withdrawal, showing a tacit concern for systemic stability. The CBR is also reluctant to withdraw licenses from banks that violate the individuals' deposits to capital ratio, because this conflicts with the tacit CBR objective to secure depositor trust and systemic stability.
\end{abstract}

Keywords: Bank supervision, bank crisis, Russia.

JEL Classification: G2 N2 E5 


\section{Introduction}

Economic research has given a lot of attention to the individual tasks of central banks, such as monetary policy, lender of last resort services, bank supervision, maintaining payments system stability and financial stability. The complementarities and conflicts between these functions have also received academic attention. There exists, for example, a potential conflict between monetary policy and systemic stability. A too narrow price stability objective may, through an accommodating monetary policy, induce a lending boom and asset price inflation. This increases the risk of systemic instability, as was the case in the Nordic bank crises of the early nineties. Kaminsky and Reinhart's (1999) finding that crises are often preceded by relaxed monetary policy, asset price bubbles and lending booms suggests that there is a trade-off between monetary policy and systemic stability. They also found that most crises were preceded by financial liberalization, probably because the financial liberalization was incomplete or not followed by appropriate regulation and supervision in the newly liberated financial sectors. This suggests another trade-off, namely one between systemic stability and individual bank supervision. In their seminal paper, Peek, Rosengren and Tootell (1999) found that the implementation of monetary policy can benefit from information obtained by prudential supervision and control of the banking system. This has heated the debate whether bank supervision should be assigned to the central bank or not (Di Noia and Di Giorgio, 1999). The possible conflicts arising from the coexistence of a lender of last resort and deposit insurance has also received academic interest (see e.g. Sleet and Smith, 2000; Repullo, 2000).

In this paper we devote attention to the conflict between systemic stability and individual bank stability, both explicit objectives of many a central bank. To assure systemic stability central banks typically take on the role of lender of last resort. This comes at the cost of moral hazard by individual banks. This conflict can be solved by prudential regulation and control (see Dewatripont and Tirole, 1994), which in several countries is in the hands of the central bank too. Bank supervision is meant to give individual banks an incentive to take less risk, in this way alleviating the moral hazard of individual banks that follows from the presence of a lender of last resort. The strict enforcement of bank regulation may however endanger systemic stability and draw the regulator to a policy of regulatory forbearance, which again creates moral hazard. In short individual and systemic bank stability may be conflicting objectives and therefore rule-based supervision of individual banks may be inconsistent with the objective of systemic stability. This could for example occur if the regulatory failure of a money centre bank or a large deposit bank threatens to affect trust in 
the interbank market or the deposit market respectively, giving rise to contagion and inflating the risk of systemic instability. This inherent conflict is even present in central banks that have neither systemic nor individual bank stability as explicit objectives, since any central bank needs a stable banking system in order to be able to conduct an effective monetary policy.

The economic literature has been aware of the conflict and there is no conclusive theory that explains how bank supervision and lender of last resort functions should be balanced. The good old Bagehot rule of 1873 -"lend freely to illiquid but solvent banks at a penalty rate"- is still defended by many authors. Goodhart $(1988,1995)$ puts forward that liquidity should not be denied to any bank a priori, since the difference between illiquidity and insolvency is sometimes hard to tell. Goodhart and Huang (1999) propose that the central bank reduces moral hazard of individual banks by employing a policy of constructive ambiguity in the bailout decision to reduce moral hazard. Other authors do not agree with this harsh policy and claim that softer policies will induce truthful reporting of asset quality and will in the end lead to cheaper bank rescues and higher systemic stability (see Povel, 1996; Aghion et al, 1999). Cordella and Yeyati (2003) claim that an ex ante central bank commitment to a bailout contingent on adverse macro-shocks is welfare superior to the policy of constructive ambiguity. Freixas, Parigi and Rochet (2000) show that, if all banks are solvent, it is optimal for the central bank to prevent a speculative gridlock in the payments system by guaranteeing the credit lines of all banks. Individual bank insolvency however should be solved by orderly bank closure whereby the central bank bypasses the insolvent bank in the interbank network to avoid contagion. They also show that it may be optimal for the central bank to show forbearance towards money centre banks, which is their interpretation of the too big to fail hypothesis (see Wall and Peterson, 1990).

Central banks also have several less straightforward incentives for regulatory forbearance. Boot and Thakor (1993) show that regulatory discretion urges reputation-seeking regulators to show more forbearance than optimal, because they are inclined to avoid failures on their book in order to leave the job with a clean slate. This suggests that a rule-based prudential control would be better. Mailath and Mester (1994) on the other hand show that if regulators cannot commit themselves, temporary forbearance may be the equilibrium outcome. In the same line, Acharya (1996) finds that regulatory forbearance may be optimal if the dead-weight losses of closure are important. Kane (2000) indicates that some banks may simply be too big to discipline adequately (TBTDA), which can lead to undesired de facto forbearance. Heinemann and Schüler (forthcoming) analyze how there may be a problem of regulatory capture (see Laffont and Tirole, 1991 for more on this) by 
specific interest groups. As a consequence one cannot be certain that the enforcement of prudential rules would be optimal for welfare even in the case of unthreatened systemic stability.

In short there is no consensus in the literature how to strike the right balance between individual and systemic bank stability if the central bank performs both prudential control and lender of last resort functions ${ }^{1}$. We look at this question from an empirical angle by analyzing one of the most intriguing cases of central banking in recent history, namely Russia. The Central Bank of Russia (CBR) is a very young central bank. From the onset in 1990 it was entrusted with monetary policy, bank regulation and bank supervision. It also plays a central role in the money circulation and the payments system and has at many occasions secured systemic stability by acting as a lender of last resort. In our data window, it was still active as a commercial bank through its giant daughters, Sberbank and Vneshtorgbank. Hence the objectives are manifold and so are the potential conflicts between them.

Specifically, we look at the CBR's supervision of Russian commercial banks. The CBR both designs the rules, within the framework of the banking law, and has the single authority to enforce them. Hence no conflict between competing regulatory agents should be expected. In April 1996, the CBR announced a set of new and revised prudential regulations to which banks need to comply to maintain their bank license. By setting bank standards the CBR intends to create incentives for banks to take less risk ${ }^{2}$. These bank standards will however only induce the desired effect on bank risk-taking if banks anticipate that the standards will be enforced. Proper enforcement involves license withdrawal as the ultimate penalty for banks in repeated violation. We refer to this as the regulatory failure of a bank. Regulatory forbearance by the CBR would impair the credibility of its own bank standards, resulting in soft legal constraints (see Perotti 2002).

The empirical question in this paper is whether the CBR's delicensing is driven by the enforcement of its own supervisory bank standards, or rather by other more tacit objectives that are related to the systemic stability of the banking system which may induce regulatory forbearance. We employ a quarterly panel of Russian banks in the period 1999-2002 and relate license withdrawal or the lack thereof to standard economic variables (i.e. we control for economic failure), to tacit objectives by the CBR in the large domain of systemic stability, and to compliance with bank standards. Controlling for economic failure, we cannot reject the thesis that tacit CBR objectives

\footnotetext{
${ }^{1}$ In developed economies bank supervision tends to fall more and more in the realm of a singly authority without central bank involvement, although it is not impossible that this trend will be reversed in the long run.

${ }^{2}$ Although Blum (1999) shows theoretically that the effect of capital rules on bank risk taking is ambiguous.
} 
skew the license withdrawal decision. We also find regulatory forbearance for some bank standards.

More specifically our results indicate regulatory forbearance by the CBR for large deposit banks (safeguarding depositor trust), banks that are active on the interbank market (safeguarding interbank market stability) and banks in already very concentrated regional bank markets (safeguarding minimal bank competition). Hence the CBR cares about systemic stability and this implies conflicts with rule-based bank supervision. We also find indications that the CBR leaves the banks that are too big to be disciplined alone, and weak evidence that banks that hold a large share of total government debt tend to be less likely to be subjected to license withdrawal. In short we find that the biases in the CBR's licensing behavior are best understood as the result of conflicting objectives at the heart of the CBR, rather than as a case of pure regulatory discretion ${ }^{3}$.

The next section describes the Russian banking sector in a nutshell and overviews the process of bank creation and bank destruction in Russia during the last 15 years. Section 3 explains our empirical approach, focusing consecutively on the data and the empirical hypotheses. In section 4 we estimate a panel logit model and interpret the results. In section 5 we perform a robustness check by estimating a survival model and reviewing the results. Section 6 concludes.

\section{The Russian banking sector in a nutshell}

\subsection{Problems of the Russian banking sector}

The Russian commercial banking sector has been plagued by a number of serious problems in the first decade of its existence.

Russian commercial banks have not adequately taken up the role of intermediary between savings and investments. In early transition banks clearly preferred speculation to lending (Schoors, 2001). Lending to the economy as a percentage of total banking assets sank year after year until 1999 and has not spectacularly improved since. In 2003 bank assets had grown only up to 42.1 per cent of GDP and loans to the non-financial sector were still restricted to just 17.0 per cent. Bank credits financed as little as 4.8 per cent of fixed investment in $2003^{4}$. With hindsight this behavior was not irrational. The presence of soft legal constraints made it very hard for banks to enforce overdue claims. Bank lending was also depressed by very large information asymmetries

\footnotetext{
${ }^{3}$ Malyutina and Parilova (2001) argue that the CBR based its closure policy on discretion rather than on its prudential regulations, but we argue that there are other 'tacit' objectives at stake.

${ }^{4}$ Data from the CBR Bulletin of Bank Statistics.
} 
between banks and their prospective customers, and by the lack of screening and monitoring skills in the banks themselves and in the economy at large. Banks were not able to discriminate between potential borrowers (Brana, Maurel and Sgard, 1999) and preferred not to lend at all. Moreover, the vast amount of very small banks and the lack of a transparent information system about their credit histories may have contributed to less lending (Pyle, 2001).

In addition the little lending that took place was mainly to the government (under various forms), as witnessed in the August 1998 crisis when several large banks became illiquid and insolvent overnight when the government defaulted on its treasury bills, or to connected parties. The widespread connected lending is partly explained by historical factors. The successors of the former specialized state banks were reluctant to restructure and continued to lend passively to their owners (Schoors, 2003). Many of the newly founded private banks have been captured by dominant shareholders. These so-called 'pocket banks' operate as the treasury of a firm or a group of firms rather than as an independent bank and they prefer 'putting their money where their mouth is' to normal relationship lending. This makes the problem of connected lending or insider lending omnipresent in Russia. Most banks predominantly lend to connected agents, regardless of the viability of the lending project, with only very weak monitoring incentives (Laeven, 2001). Note that the government too is to some extent a connected party, because several banks are captured by local, regional or national governments. At the start of 2003, Russia had 23 banks in which the state (federal or regional authorities) held majority stakes, the regional authorities hold minority stakes in many more banks and a large number of state unitary enterprises were part-owners of banks (Tompson, 2004).

The problem of connected lending combined with the presence of soft legal constraints, information asymmetries and the lack of screening and monitoring skills implied that the Russian banking sector was riddled by bad loans well before the 1998 crisis. A leaked analysis of Russian banks after the crisis of August 1998 shows that the major loss of capital for banks was not the devaluation loss or the government default on treasury bills (the famous GKO), but bad loans that had been left to perish in their balances already for some time ${ }^{5}$. The banks had been hiding these bad loans. Schoors and Sonin (2005) explain that the Russian banking system was stuck in a passivity trap, where it was rational for all banks to hide bad loans rather than to enforce them. The real growth that took place since 1999 has allowed the Russian banks to 'grow' their way out of bad loans, but we should keep in mind that loan quality is in the end a flow rather than a stock variable. It will

\footnotetext{
${ }^{5}$ See The newly-wed and the nearly dead, Euromoney, June 1999.
} 
not go away unless the nature of the flow changes.

The Russian banking sector also suffered from poor capitalization when compared to liquid assets (deposits and interbank loans), especially considering the poor quality of assets and the large exposure to exchange rate risk ${ }^{6}$. This overexposure was revealed when the devaluation in August 1998 sent many Russian banks from positive to negative capital overnight (Perotti, 2002). The CBR has steadily raised capital standards since 1999, but bank capitalization is still substantially lower in Russia than in developed banking markets. Our data also reveal that average capitalization is substantially higher than the weighted average capitalization, indicating that precisely the largest banks have the weakest capitalization, not exactly a comforting result. The difference is most pronounced when total bank deposits are used as weights, implying that the buffer of capital is lowest in the banks that need it most.

Many banks were liquidated or simply vanished. Sometimes this was due to a combination of the above factors (poor capitalization, too much speculative risk, endemic bad loans, connected lending etc.), but there were also a large number of financial scandals and scams, where depositors were simply cheated by crooks that fled with their money. The very soft legal constraints faced by banks encouraged asset stripping by the management and the owners, leaving the creditors to bear the brunt of the cost of failure (Perotti, 2002). As a result, popular distrust of the banking system became rampant and depositors gradually shifted their money to Sberbank and Vnestorgbank, the former state banks that are still in the state's hands (see OECD, 2004). Sberbank has a huge branch network and carries a government guarantee. The government lent credibility to this guarantee by supporting Sberbank if needed and using it as a device to absorb deposits from large defunct deposit banks in the aftermath of the 1998 crisis. The same holds for Vneshtorgbank, as demonstrated in the mini-crisis in May-July 2004 when Vneshtorgbank finally acquired Gutabank, one of the larger deposit banks under attack. As a result Sberbank and Vneshtorgbank dominate a very concentrated deposit market. Figure 1 shows Herfindahl indices for deposits in several federal districts and reveals that deposit markets were highly concentrated in the period 1999-2002, although regional differences were substantial.

Note also that there was no true national banking market, be it in commercial lending, deposits, interbank lending or even foreign exchange trading. Only very few banks had nation-wide branch networks and banks distrust each other. After the 1998 crisis, the only remaining banks with a national scope were Sberbank and arguably Vneshtorgbank, then still both daughters of the

\footnotetext{
${ }^{6}$ See, for example, Buch and Heinrich (1999).
} 
$\mathrm{CBR}^{7}$. Regional disparities in the Russian banking sector are huge. In the period under study, some regions still enjoy an acceptable amount of competition, while other regions exhibit very high concentration. This can be seen from the regional data on bank branches per capita in figure 2. Regions have on average only 2 bank branches per 100000 inhabitants, which is very little to European standards. The large regional differences in concentration are demonstrated in figure 3, that exhibits regional Herfindahl indexes for bank assets. The absence of a national market can also be seen directly from the substantial differences in regional interest rates and even exchange rates $^{8}$, that can only be sustained by fragmented markets. Note that the deposit market (figure 1) is even more concentrated than the banking sector as a whole (figure 3).

\section{Insert figures 1 to 3 here}

It is clear that by 1998 bank restructuring had been long in the waiting. Several observers and notably the IMF repeatedly expressed hope that the 1998 crisis would finally urge the CBR to undertake serious bank restructuring. In the immediate aftermath of the crisis, the CBR itself indicated that it expected 400 to 600 banks to disappear. These expectations were dashed soon enough, mainly because the banks themselves faced very soft legal constraints. Consequently many of the banking system characteristics remained fundamentally unchanged.

\subsection{An overview of bank creation and bank destruction in Russia}

Since we study bank licensing behavior of the CBR, an introductory description of the big trends in CBR bank licensing is required.

\section{Insert figure 4 here}

Figure 4 shows the detailed dynamics of monthly bank creation and destruction in Russia. It is based on data that are freely available on the CBR-website. The solid line shows new bank registrations, while the dotted line shows bank licenses withdrawn in a given month. We first turn to bank creation. There is a striking peak of bank creation at the end of 1990: 228 banks were created in October 1990, 347 in November 1990 and 269 in December 1990. This peak is to a large extent explained by the secessionist privatization of the former state banks (spetsbanki) that started in 1988 - well before the collapse of the Soviet Union in December 1991 - and continued initially unattended. This secessionist privatization yielded over 600 often unrecognizable state-bank successors

\footnotetext{
${ }^{7}$ Note that in 2004 ownership of Vneshtorgbank moved from the CBR to the state directly.

${ }^{8}$ These numbers can be found in the CBR publication Bulletin of Bank Statistics, available in English on the CBR website.
} 
as explained in detail by Schoors (2003). At the same time, individuals, governments, corporations and other organizations created a number of new banks. Bank creation by economic agents other than former state banks took off spectacularly in 1992-1994. Many of these new banks were however casinos rather than banks or, worse, smartly clad crooks (the MMM pyramid of Sergey Mavrodi being the obvious example). This was partly due to the very relaxed bank supervision by Viktor Gerashenko, the former president of Gosbank and the president of the CBR since the summer of 1992, when the hard-nosed but unexperienced CBR president Matyukhin was outmaneuvered by the industrial lobby. The bank creation numbers suggest that bank supervision was tightened from 1995 on, under the reign of Tatiana Paramonova. The process of bank creation dropped sharply and remained very low from 1996 onwards. This was due to the introduction and enforcement of stricter minimum capital requirements in April 1996 under the reign of the Sergey Dubinin at the helm of the CBR. Only in 2001 the rate of bank creation picked up to a meaningful level again.

Bank destruction follows a different pattern altogether. There is a peak of license withdrawals in the first half of 1992 when the CBR was headed by the new and hard-nosed reformer Matyukhin. Under political pressure, he was replaced in mid 1992 with Gerashenko, the last president of the defunct Gosbank, the former state monobank that ceased to exist together with the Soviet Union by end December 1991. Immediately the number of license withdrawals dropped to substantially lower levels. Indeed from mid-1992 until end 1994, the CBR had a very relaxed policy towards bank licensing and bank refinancing and banks were awash with liquidity (Schoors, 2001). This left Russia with well above 2000 banks by end 1994. The exchange rate crisis in October 1994 cost Gerashenko his position as president and he was replaced with the more reform-minded Paramonova. She made a first sweep of the banking sector in early 1995, to clean up the mess of the exchange rate crisis. A second wave of license withdrawals peaked in November 1995 in the aftermath of the meltdown on the Russian interbank money market in August 1995. Apparently the CBR reacted to crises by enforcing some of its regulations ex post, a pattern of behavior it has continued ever since. Once the new chairman of the CBR, Dubinin, came into power he swept through the licenses in May 1996, after the introduction of new minimal capital requirements, and repeated this exercise in March 1997. Still the majority of banks that lost their license under Paramonova and Dubinin were very small banks without political clout. In several cases the bank was already bankrupt, or even worse, had been looted by its directors. In this sense the CBR was, even in the apparent good times of 1995-1997, following events rather than anticipating them.

With the crisis of August 1998 Dubinin had to go and Gerashenko emerged again at the helm of the 
CBR to sort out the mess. He achieved the stabilization of the banking system and sorted out the clogged payments system by bailing out the banks without enforcing a change in their behavior. Officially there was an "Agency for the Restructuring of Credit Organizations" (ARCO) ${ }^{9}$, but it was underfunded and did not achieve much in the way of bank restructuring. Figure 4 indicates that the pace of license withdrawal did not pick up but fell instead to very low levels. This was not only due to Gerashenko's weak policy but also resulted from a striking but well hidden deficiency in Russian law, namely the exemption of banks from the bankruptcy code, a dreary detail of which many foreign creditors were not fully aware. This ensured that creditors could not easily enforce their claims on banks. The banking sector had insisted on this exemption and was thereafter successful in blocking all draft laws on bankruptcy of banks until a law 'on the restructuring of credit organization' finally came into force in March 1999. This legal loophole gave less benevolent banks the opportunity to loot creditors by stripping banks from their valuable assets and transferring them to so-called bridge banks. This procedure was practiced on a grand scale in the aftermath of the 1998 crisis. Insolvent institutions transferred their valuable assets to bridge banks, while leaving the liabilities in the defaulting or troubled institutions. Foreign creditors were furious and when the March 1999 law came into power, the IMF strongly pressed the CBR to perform at least some restructuring. As a consequence some high profile banks lost their license, among which Promstroibank and Mosbusinessbank, two direct successors of the former specialized state banks. These bankruptcies were however more symbolic then real. Their smooth death had become convenient to all parties, the creditors excluded. This again had much to do with the stipulations of the new law and the choices of the CBR. The March 1999 law provides that creditors can only take a bank to bankruptcy after the CBR has withdrawn the license. In practice the CBR often waited too long to withdraw the license, in this way delaying bankruptcy proceedings and allowing the looting to take place. All too often licenses were only withdrawn when the bankruptcy of the empty and illiquid shell had become convenient to all parties, with the notable exception of creditors. This pattern of convenient bankruptcy was typical of the process of 'mired restructuring' that took place after 1998 (Schoors, 1999).

\footnotetext{
${ }^{9}$ See Mizobata (2002) and Tompson (2002) for more on this topic.
} 


\section{Empirical approach}

We analyze the licensing behavior of the CBR in the period 1999-2002. This period is chosen because of four reasons. First, most of the casinos, exchange offices, extremely small banks and smartly clad crooks had already disappeared from the system by virtue of the successive sweeps through the bank licenses in the period 1995-1997 (see previous section). Most of the banks in the sample therefore perform at least some of the standard bank functions. Second, we want a period with a consistent regulatory policy, since the various CBR presidents in the past have shown widely different supervisory preferences. In 1999-2002 bank licensing behavior is - again - in the hands of Viktor Gerashenko, who emerged at the head of the CBR after the 1998 crisis. Third, in 1998 the CBR introduced a new accounting system that moves away from Russian accounting standards (RAS) in the direction of international accounting standards (IAS). This renders it much more difficult, though not impossible, to compare bank data before and after the crisis, unless a major conversion effort is undertaken. Last, the new law on bank restructuring that came into effect in March 1999 gave the CBR a central role in bank restructuring, which was expected to strongly affect the CBR's licensing behavior.

We use data from three sources, namely Interfaks, Mobile and the CBR. We describe the data in detail in appendix A. In section 4 we estimate a panel logit model, where the dependent variable will be a dummy variable equal to 1 for every bank quarter that sees a license withdrawal and 0 otherwise. In section 5 we turn to bank license survival as a dependent variable and perform a survival analysis. We will relate license withdrawals and bank survival to three groups of variables, namely 1) compliance to regulatory standards, 2) variables that capture the tacit objectives of the central bank, and 3) economic (bank- and market-specific) variables, predicted by economic theory. In the rest of this section we list all variables, explain why we use them and how exactly we calculate them.

\subsection{Compliance with regulatory standards}

For each prudential bank standard in each quarter, the dataset tells us how the bank scores. From the legislation and from CBR documents we know how banks are supposed to score on each bank standard in each quarter (see appendices A and B for a detailed description). If the score does not satisfy the standard, we have a breach of the standard. We use this information on breaches to construct measures of individual bank compliance to the CBR's regulatory standards. We start 
observing bank-specific scores on bank standards at time $t_{0}^{P R 10}$.

We construct several vectors of variables that are assumed to measure compliance with CBR standards. For each bank standard, we have the bank-specific scores on a quarterly basis. Based on the definition for each bank standard $n$ and its regulatory minimum or maximum imposed by the CBR, we define standard -specific breaches and count these breaches per bank and per bank standard. However, counting the number of breaches is cumbersome for two reasons. First we want the number of breaches to be time-varying, but this implies that the total number of breaches will be higher for later quarters. We get round this problem by a simple correction. Secondly, some banks are created after $t_{0}^{P R}$, which means that they will have less bankquarters in the sample and ceteris paribus will register less breaches. This also calls for a correction. Therefore we correct the simple sum of breaches for bank $i$ until $t$ by dividing it by the maximal number of possible breaches at time $t$ and multiplying it by the number of breaches that is maximally possible for banks created before $t_{0}^{P R}$ and still alive in $t$. More specifically, we define for each regulation $n$ and for each bank $i$, the number of past breaches at time $t$ :

$$
\text { nbreach }_{n, i, t}=\frac{\sum_{z=k}^{t} \text { breach }_{z}}{t-k}\left(t-t_{0}^{P R}\right),
$$

with breach equal to one when a bank violates the rule and zero otherwise, $k$ the start of observations for the bank $i$ and $t$ the observed bank quarter for bank $i$. Figure 5 illustrates what this implies for banks with different dates of entry.

\section{Insert figure 5 here}

A second measure takes into account that the CBR possibly attaches more importance to current breaches than to past breaches. Put simply, a bank which violated twice during the previous two quarters has the same score on nbreach at time $t$ as a bank with only two breaches last year, while one might expect the $\mathrm{CBR}$ at time $t$ to attach more value to the former than to the latter. We construct a second vector of compliance variables that discount past breaches.

Define the weights:

$$
\varpi_{t}=\alpha(1-\alpha)^{t}, \text { with } \sum_{t=0}^{\infty} \varpi_{t}=1 .
$$

\footnotetext{
${ }^{10}$ For most bank standards, this is in 1997:Q2. For N10.1 this is in 1997:Q3 and for N9.1 this is in 1998:Q1, because these standards were introduced later. The data between 1997:Q2 and 1999:Q1 on scores of banks on prudential bank standards are from Mobile. For 1999:Q2 -2002:Q4 the scores on bank standards are from Interfaks. See appendix A for a detailed description of the different datasources available for Russian banking and their compatibility.
} 
Then the discounted number of breaches for each regulation $n$ and a given bank $i$ at time $t$ is:

$$
\text { dnbreach }_{n, i, t}=\frac{\sum_{z=k}^{t} \varpi_{t}\left(\text { breach }_{z}\right)}{t-k}\left(t-t_{0}^{P R}\right) .
$$

In order to compare the coefficients of the two variables in the regressions, they should have the same measure. However the sum of the weights used to calculate dnbreach equals unity, while implicitly the sum of the weights used to calculate nbreach equals $t-k$. Therefore we adjust the measure for dnbreach by multiplying again with $t-k$, which gives:

$$
\text { dnbreach }_{n, i, t}=\sum_{z=k}^{t} \varpi_{t}\left(\text { breach }_{z}\right)\left(t-t_{0}^{P R}\right) .
$$

The CBR may also care for the average severity of breach, rather than the number of breaches. We therefore construct a third variable for each norm $n$ to capture this notion:

$$
\text { sbreach }_{n, i, t}=\frac{\sum_{z=k}^{t}\left(\frac{\mid \text { score }_{z}-\operatorname{standard}_{z} \mid}{\operatorname{standard}_{z}}\right)}{t-k} .
$$

Obviously we calculate this as a one-sided variable. Specifically the deviation of the score from the standard is only counted in the case of a breach and equal to zero otherwise. We take absolute values to ensure that a breach is always defined as a positive number. Again, one can assume that the CBR cares more about the severity of current breaches than about the severity of past breaches. The discounted severity of breach is then defined as:

$$
\text { dsbreach }_{n, i, t}=\frac{\sum_{z=k}^{t} \varpi_{t}\left(\frac{\mid \text { score }_{z}-\text { standard }_{z} \mid}{\text { standard } z_{z}}\right)}{t-k},
$$

To ensure comparability of the coefficients, we need again multiply with $t-k$, which gives:

$$
\text { dsbreach }_{n, i, t}=\sum_{z=k}^{t} \varpi_{t}\left(\frac{\left|\operatorname{score}_{z}-\operatorname{standard}_{z}\right|}{\operatorname{standard}_{z}}\right) .
$$

Possibly the CBR cares about the total volume of breaches, rather then the number of breaches or their average severity. We therefore construct a variable that captures the total volume of breaches. This should be interpreted as the one-sided total distance over time for a given bank between any bank standard $n$ and the bank's actual score on the standard:

$$
\text { vbreach }_{n, i, t}=\text { nbreach }_{n, i, t} * \text { sbreach }_{n, i, t}
$$


There is a last twist in the measurement of compliance variables. For some banks in some quarters, the scores on bank standards are missing. Apparently some banks sometimes fail to report their score to the CBR. These non-reported bank scores can be interpreted as compliance, as noncompliance or as something in between by the CBR. Rather than making assumptions about this in the calculation of the compliance variables, we will introduce a dummy variable for non-reported bank scores in a given bank quarter as a separate variable in the regressions, allowing the data to decide how the CBR interprets missing values. We will in fact find that banks which often fail to report are much more likely to loose their licence and are less likely to survive. This indicates that the CBR interpretsnon-reported scores as a very bad signal of underlying bank health or alternatively that banks that expect to loose their license anyhow do not even bother to submit their scores on the bank standards any longer.

\subsection{Tacit objectives of the CBR}

Regional banking coverage The CBR feared that in some regions banking became too concentrated. ARCO has indicated it supported some banks with regional networks to avoid that some regions would become underbanked (Mizobata (2002) and Tompson (2002)). We therefore expect that banks in already very concentrated regional banking markets are less likely to lose their license, as compared to identical banks in less concentrated regions. As a concentration measure, we use the regional Herfindahl index, calculated as the sum of squared regional market shares for each region $j$ and quarter $t$ :

$$
\sum_{i=1}^{n_{j}}\left[\left(M S_{i j t}\right)^{2}\right] .
$$

The regional banking coverage is very stable in our data window, with some very poor and some very well banked regions. The very low variability of this variable in our sample implies that it is not fit to explain quarter-specific variance in the bank licence withdrawal behavior of the CBR. Therefore, in the estimations we will employ the average of this variable over time such that we have one observation per region.

Systemic stability The CBR cares about systemic stability which is likely to lead to biases in its (de-)licensing behavior. We will look at the following variables:

- The CBR may wish to protect banks that are active on the interbank market to minimize 
the risk of contagion. As a proxy for banks that are active on the interbank market, we use the ratio of interbank liabilities $I L$ to total liabilities $T L$.

- The CBR may wish to specifically protect money centre banks to enhance the stability of the interbank market. If some large banks at the heart of the interbank system fail, the whole banking system could collapse ${ }^{11}$. The CBR will want to avoid this out of motivations of systemic stability ${ }^{12}$. This cannot be captured by the relative importance of interbank liabilities $I L$ in bank-specific liabilities. Since all important banks are active on the Moscow interbank market, we include the interbank market share $M S I L$ in total interbank liabilities:

$$
M S I_{i t}=\frac{I L_{i t}}{\sum_{i=1}^{n} I L_{i t}}
$$

- The CBR may wish to protect large deposit banks to avoid deposit runs ${ }^{13}$ and restore trust in the banking sector. Interestingly, this can be measured by the regulatory bank standard N11 (household deposits over capital). We expect therefore to see forbearance of breaches of N11, since enforcement of this standard is not consistent with other CBR objectives (see appendix B for a more detailed description of this bank standard).

\section{Political influence}

- We include the ratio of government claims $G$ to total assets $T A$ to measure government capture. Banks that lend relatively more to the government may have more political clout and receive protection against de-licensing. When banks have a lot of government bonds in their portfolio, the CBR might prefer not to close the bank when it has an interest in distributing these bonds. This was actually the case for GKOs prior to 1998 (Malyutina and Parilova, 2001).

- Possibly, we need to look at the portfolio of the Ministry of Finance, rather than the individual bank portfolio. Specifically, the CBR may mainly be captured by banks that hold a large

\footnotetext{
${ }^{11}$ See, for example, Wall and Peterson (1990) on the FDIC bailout of Continental Illinois and Kapstein (1994) and Davis (1992) on the failure of Herstatt Bank.

${ }^{12}$ Freixas et al. (2000) show that it may be too costly to close down money centre banks because it might trigger the liquidation of all other banks. See also Rochet and Tirole (1996) on this point.

${ }^{13}$ Models of a bank runs include Diamond and Dybvig (1983), Postlewaite and Vives (1987), Wallace (1990), Chari (1989), Champ, Smith and Williamson (1996), Alonso (1996).
} 
absolute amount of government claims $G$ (mainly bonds). Indeed the government may be less than willing to liquidate its largest financiers, while smaller banks are less important. Therefore we include the government portfolio market share $M S G$ in total government claims:

$$
M S G_{i t}=\frac{G_{i t}}{\sum_{i=1}^{n} G_{i t}}
$$

- The CBR may be less willing to sort out pocket-banks. These banks are often dominated by very powerful but closed groups with a lot of political clout, tend to be isolated from the rest of the banking sector and hardly take any household deposits. Therefore the CBR has few incentives, from the point of view of systemic stability, to enforce bank standards N9.1 and N10.1 and strong political incentives to show forbearance for breaches of bank standards N9.1 and N10.1 (see appendix B for a more detailed description of these bank standards).

Too big to be disciplined adequately Some banks may be simply too big to fail. This can be justified on the grounds that the collapse of a large bank poses a threat to the banking system as a whole (see Wall and Peterson, 1990). This is already measured in our analysis by the interbank market share that identifies money centre banks. There is also evidence that the CBR gave a lot of credit to the largest banks (Malyutina and Parilova (2001)), which in turn lowered its incentives to close down these banks as the cost of closure increased, but we do not unfortunately have this information. Kane (2000) indicates that some banks may simply be too big to discipline adequately (TBTDA), rather than too big to fail, which creates a problem of undesired de facto forbearance even in developed market economies like the US. This may certainly be a problem in Russia, where the understaffed and relatively young department of bank supervision is not up to the task of controlling really large banks with their complex activities and intricate balances. We measure the TBTDA-bias in licensing behavior by including bank size (the log of total assets), which should be positively (negatively) related to survival (license withdrawal) probability.

\subsection{Economic variables}

We include a set of bank- and market-specific variables which are expected to influence license withdrawal, next to (non-)compliance with prudential regulation and variables related to tacit CBR objectives: 
- A high return-to-assets ratio $R O A$ should reduce (increase) license withdrawal probability (survival).

- The cost-to-assets ratio is expected to be positively (negatively) correlated with license withdrawal (survival).

- The ratio of interbank liabilities to total liabilities $I L / T L$ is an indicator of the liquidity of liabilities and should be positively (negatively) correlated with license withdrawal (survival) (Calomiris and Mason, 2000).

- The regional market share in assets is a proxy for market power. In the structure-conductperformance framework the effect of market power on license withdrawal (survival) is expected to be negative (positive).

$$
M S A_{i j t}=\frac{T A_{i j t}}{\sum_{i=1}^{n} T A_{i j t}}
$$

- Poor loan quality as measured by the ratio of non-performing loans $N P L$ to total loans $T L$ should increase (reduce) the license withdrawal probability (survival).

- The ratio of total reserves (including excess reserves) $T R$ to total assets $T A$, as an indicator of absolutely safe liquidity, should reduce (increase) license withdrawal probability (survival).

\subsection{Contradictory hypotheses}

There are some clear contradictions in the above hypotheses:

1. Either the CBR enforces N11 or it protects large and weakly capitalized deposit banks, which implies forbearance.

2. Either the CBR enforces N9.1 and N10.1, or it prefers to leave pocket banks alone, which implies forbearance.

3. Large holdings of government bonds either protects banks against de-licensing because of government capture or accelerates bank demise because of the government's default on treasury bills in August 1998 and the subsequent liquidity problems in the banks concerned. 
4. Either the CBR protects banks that are active on the interbank market (high $I L / T L$ ) or these highly liquid liabilities make banks more vulnerable and therefore more likely to fail as suggested by Calomiris and Mason (2000).

Table 1 summarizes the definitions and sources of all the variables described above.

\section{insert table 1 around here}

\subsection{Summary statistics and correlations}

Summary statistics for all variables are given in table 2. Note that we excluded Sberbank, Vneshtorgbank and Vnesheconombank from the sample. They are totally dominated by the CBR and their survival is ensured in any case. This still leaves us with more than 20000 bank quarters of data available for estimations. Table 2a shows summary statistics for the economic variables and the variables that measure tacit CBR objectives. The Moscow control variable reveals that $48 \%$ of bank quarters are from banks registered in the Moscow region. All other variables show reasonable average values. The ratios are never below zero and never above $100 \%$, although some bankquarters actually reach the maximum of $100 \%$. The regional Herfindahl index indicates that there is quite some variation in bank concentration across regions.

The summary statistics of regulatory compliance variables in table $2 \mathrm{~b}$ reveal that the maximum number of breaches is for some bank standards disconcertingly close to 23 , the number of bank quarters used for the calculation of the compliance variables. Apparently some banks have been breaching some standards in almost all bank quarters and still managed to keep their banking license. Bank standard N11 (individuals' deposits to capital) is on average breached most often (on average in 1.54 quarters on a total of 23 quarters) and the breaches are on average relatively severe (13\% away from the standard). Also the capital adequacy standard is breached quite often (on average in 0.53 quarters out of 23) and relatively severely (on average $19 \%$ away from the standard). Next, the liquidity standards are regularly breached by commercial banks. From the summary statistics on the volume of breaches (table $2 \mathrm{~b}$, lower panel) the most severely breached bank standard is the deposits to capital ratio N11, closely followed by a number of liquidity standards and the capital adequacy standard. Still on average banks breach the standards neither terribly often nor terribly severely. In addition, the minimal values for the compliance variables in tables $2 \mathrm{~b}$ are always 0: For every bank standard, one can always find at least one bank that complies all the time. 
Correlations between the variables are shown in table 3. There is one noteworthy source of correlation, namely the compliance variables of liquidity standard N5 that seem to be highly correlated to compliance with other liquidity standards. This is not surprising given the very general definition of this liquidity standard. Besides, one could question the usefulness of such a liquidity standard in the Russian setting. Indeed the standard N5 only looks at very broadly defined liquid assets, but it neglects all aspects of assets/liabilities management. Having high liquid assets only adds to bank health in the presence of corresponding highly liquid liabilities. Banks that score very well on this standard have in fact only shown to hold few real bank assets (loans).

\section{Insert table 2 and table 3 here.}

We are not only interested in the number of bank quarters, but also in the number of banks used in the estimations. Table 4 reveals that the more than 20000 bank quarters cover 1509 banks of which 226 loose their license in the sample period. Most withdrawals are, according to the CBR announcement, due to violation of bank regulation (more than 25\%) or compulsory bankruptcy (more than 53\%). In practice these two reasons for withdrawal overlap in many cases. Economically

bankrupt banks tend to violate a number of bank standards. Hence our compliance and economic variables should do well in picking up these license withdrawals in the empirical analysis. Table 4 also shows that more than $17 \%$ of the licenses disappear because of bank mergers. These mergers could hide bank failure (mergers to avoid license withdrawal or economic failure), but could also be genuine mergers for strategic reasons as indeed most banks are far to small to be economically efficient. To test how the treatment of mergers affects our results, we will alternatively include and exclude mergers in the sample of banks that loose their license, as a robustness check.

\section{A logit model}

We first use a logit model to investigate the competing hypotheses affecting a bank's probability of license withdrawal. Specifically we estimate the specification:

$$
\begin{aligned}
\text { Prob }(\text { license withdrawal })_{i, t}= & c+\alpha_{i, t-1}^{\prime}(\text { economic variables })+ \\
& \beta_{i, t-1}^{\prime}(\text { tacit CBR objectives })+ \\
& \gamma_{i, t-1}^{\prime}(\text { compliance measures })+v_{i}+\varepsilon_{i, t} .
\end{aligned}
$$

The dependent variable is a dummy variable which equals one in the quarter when a bank loses 
it license, and zero otherwise. The independent variables are described in detail above. We control for inflation, by including the deflator. We also include MOSCOW, a dummy variable that equals one if the bank is registered in the Moscow region and zero otherwise, because there may be some unidentified licensing bias for Moscow-based banks. In all specifications we allow for bank-specific unobserved heterogeneity, since banks may differ in ways that are not observed in our dataset. The logit model is therefore estimated under the random effects (RE) assumption ${ }^{14}$. Results are reported in table 5 .

\section{insert table 5 here.}

Panel A of table 5 shows the estimation results using the standard compliance measures. In columns 1-3 we show the results with mergers excluded. Column 4-6 show results with mergers included as license withdrawals. Our first observation is that the economic variables do reasonably will in explaining license withdrawal. Less profitable banks, banks with higher costs, banks with poorer loan quality and banks with less liquidity are all more likely to loose their banking license. Having high interbank liabilities however does not increase economic vulnerability as predicted by Calomiris and Mason (2000). Instead higher interbank liabilities contribute significantly to a lower likelihood of license withdrawal in all specifications with the number of breaches as compliance variable, while being insignificant in the other specifications. If anything, this suggests that the CBR is more reluctant to withdraw licenses from banks that are active on the interbank market and provides a first indication that tacit objectives may be guiding the CBR in its licensing policy.

The results also suggest that the CBR's licensing policy is guided by other concerns than economic variables or compliance with bank standards alone. Some of the tacit CBR objectives identified in our study do surprisingly well in explaining bank delicensing. Controlling for return to assets, cost to assets, bank liquidity, local market power and compliance to bank standards, banks in poorly banked regions are less likely to loose their license as shown by the strongly significant coefficient on the regional Herfindahl index. Large banks are still less likely to face withdrawal, suggesting that some banks are simply too large to be disciplined adequately. Holding an important share of total government liabilities also helps to avoid license withdrawal. Indeed the sign on the government portfolio share is consistently negative, although often not significant. Note however that holding a large amount of government securities relative to assets unambiguously increases the likelihood of license withdrawal. This is probably still the effect of the government default in

\footnotetext{
${ }^{14}$ We assume that there exists some time-invariant bank-specific factor (for example political strings or managerial skills) which explains part of the license withdrawal probability.
} 
August 1998. So we find that holding government securities is bad for a bank license, but less so for banks that really hold a lot of these securities. Money centre banks do not enjoy additional protection from license withdrawal beyond the protection enjoyed by all banks that are active on the interbank market (as revealed by the negative sign for the interbank liabilities variable).

As regards the compliance measures, most of them show no significance, suggesting regulatory forbearance in the CBR's delicensing policy. The variable on non-reported scores on bank standards is very positively related to license withdrawal. Apparently a bank's failure to report its scores on the regulatory standards does not go down well with the CBR. Some of the liquidity standards show up, but often with inconsistent signs, but this may be due to multicollinearity. Only the quick liquidity ratio seems to be enforced consistently, but this is not necessarily good news. It seems that the CBR may still be running behind the facts, mainly de-licensing totally illiquid banks whose failure has become convenient to it owners. Important standards such as capital adequacy, large risks to capital, or the individual deposits to capital ratio, show nothing much in the way of enforcement. Quite on the contrary some even tend to have the wrong sign, although not significant. Note also that the banks standards related to insider banks (N9.1 and N10.1) show some signs of enforcement only if mergers are included (see column 4). Apparently banks in violation with the insider-related standards tend to merge in order to solve the problem, rather than loose their license.

The results of panel A may be biased since the CBR is implicitly assumed to attach equal weights to present and past bank behavior. In panel B of table 5 we report specification (1) and (2) of panel A (mergers excluded), but now with the discounted compliance measures that attach more weight to current violations of bank standards than to past violations. The discount parameter $\alpha$ is set alternatively to $0.3,0.5$ and 0.7 , increasingly putting more weight on current violations. In the the first three columns of panel B we run specification (1) of panel A with three versions of the discounted number of breaches as compliance measures. In the last three columns of panel B we repeat specification (2) of panel A, but now with three versions of the discounted severity of breach as compliance measures. Results for the economic variables and the tacit CBR objectives are equivalent with the results in panel $\mathrm{A}$.

There are however substantial changes for the compliance variables. Not reporting scores still goes down very badly as shown again by the strongly positive sign for the non-reported scores dummy. We now however find consistent indications for the enforcement of the capital adequacy standard, the quick liquidity ratio, the current liquidity ratio and the general liquidity ratio. Indeed, if these variables show up significantly in panel B it is always with a positive sign, indicating that 
more breaches and more severe breaches of the bank standard are related to higher probability of license withdrawal. The broad enforcement of liquidity standards is not necessarily good news. It suggests that the CBR may still be running behind the facts, mainly de-licensing already illiquid banks (that may be illiquid because of asset stripping in the face of expected de-licensing) instead of anticipating future trouble. Also the insider-related standards (N9.1 and N10.1) now show enforcement when mergers are excluded, which was not the case in panel A. Apparently current violations of the pocket bank-related standards yield a disciplinary reaction from the CBR, while in the past these problems were solved by mergers. All in all, the results suggests that the enforcement of prudential bank standards by the CBR has improved.

However the large risks to capital ratio does not show strong enforcement and the individuals' deposits to capital ratio (N11) shows no enforcement at all. On the contrary the sign for N11 is even consistently negative. This corroborates our hypothesis that the enforcement of this standard would affect precisely these banks that are most active on the deposit market, which runs counter to the CBR objective of securing and restoring depositor trust and systemic stability. A conflict between two inconsistent CBR objectives is sharply revealed here.

\section{A survival model}

As a robustness check, we employ a survival model framework to estimate the expected survival time of a bank's license as a function of our three groups of determinants. The dependent variable is the survival time of a bank, $t$. We define survival time as the time that elapses between the quarter in which the CBR issued the bank's license and the quarter in which the license was revoked. The exit rate or hazard function is defined as:

$$
h(t)=\frac{f(t)}{1-F(t)}=\frac{f(t)}{S(t)}
$$

We estimate:

$$
\begin{aligned}
F(t)= & c+\alpha_{i, t-1}^{\prime}(\text { economic variables })+ \\
& \beta_{i, t-1}^{\prime}(\text { tacit } C B R \text { objectives })+ \\
& \gamma_{i, t-1}^{\prime}(\text { compliance measures })+v_{i}+\varepsilon_{i, t},
\end{aligned}
$$

where $F(t)$ represents a distribution function over duration $t$ and $S(t)$ is the survivor function. 
For each bank, the hazard rate at time $t$ is defined as the probability of license withdrawal at time $t$, conditional on having the license until time $t$. Once the functional form for the probability distribution $F(t)$ is specified, the hazard rate and the distribution of duration $t$ are completely known and can be made dependent on bank-specific covariates. We use the Akaike Information criterion (AIC) to select the appropriate specification for $F(t)$. We estimate survival models for the exponential, Weibull, Gompertz and loglogistic hazard specification. Based on the reported loglikelihoods for the different specifications, we construct the AIC as $-2($ loglikelihood $)+2(c+p+1)$, where $c$ is the number of model covariates and $p$ the number of model-specific ancillary parameters. The scores of the various models on the AIC criterion are reported in table 6 .

We select the model which minimizes the AIC and report the estimation results for the selected survival model in table 7. For the hazard estimations, the issue of unobserved heterogeneity (frailty) is somewhat more elaborate. Since we do not have left censoring ${ }^{15}$, we could handle unobserved heterogeneity on the bank-level by using the Heckman and Singer (1984) estimator ${ }^{16}$. This estimator is non-parametric with respect to the density of unobserved heterogeneity and can estimate the parameters of the distribution of unobserved heterogeneity and of the hazard function consistently. We instead estimate a model where heterogeneity is allowed and incorporated as a random effects specification. More specifically, we do assume a specific parametric representation of the distribution of the unobserved effect. In the regression results we report an extra parameter, theta, which is an estimate of the frailty variance component. The likelihood ratio tests indicate that there is only negligible bank-specific heterogeneity ${ }^{17}$.

\section{Insert table 6 and 7 around here}

The results in table 7 have the same structure as the results in panel B of table 5 . We have restricted ourselves to results with mergers excluded and discounted compliance variables. The other specifications of table 5 (mergers included, volume of breach compliance measures, non-

\footnotetext{
${ }^{15}$ Although our sample is restricted to banks that were still holding a license in the first quarter of 1999, we observe the complete survival history for all banks and therefore do not have the problem of left-censoring in the hazard specifications. We do have have right-censoring (we do not observe bank balances after 2002), which is taken into account in the construction of the likelihood function.

${ }^{16}$ They assume that the unobserved heterogeneity is a bank-specific component which is assumed constant over time and distributed over the population with a mixing distribution.

${ }^{17}$ Because we have already controlled for bank-specific characteristics, we could alternatively assume that there is still some observational frailty present in the data in stead of bank-specific unobserved heterogeneity. After selecting the appropriate parameterizations for this alternative specification, we still find only limited presence of heterogeneity. These results are available upon request.
} 
discounted compliance measures) are available on request. In the first three columns of table 7 we use the discounted number of breaches as compliance measure, in the last three columns of table 7 we use the discounted severity of breach as compliance measure. The only difference between table $5 \mathrm{~B}$ and table 7 is the econometric technique employed and the exact definition of the dependent variable, which is now survival time instead of a probability of license withdrawal. Because of the different econometric technique we expect opposite signs in table 5 and table 7 .

For the economic variables the results are very comparable to the logit model. The main difference is that loan quality seems to have no impact on bank survival, while it was a good predictor in the logit model. The finding that banks with large interbank liabilities show longer survival in all specifications of table 7 reinforces our previous conclusion that banks that are active on the interbank market enjoy some protection, again hinting at the presence of tacit CBR objectives. As regards other tacit CBR objectives we find again that banks in poorly banked regions and banks that are too big to be disciplined adequately live longer. It is less clear now whether holding a large share of assets in government securities is really so bad for bank survival, since this variable is only significant once in table 7 , and the sign is not consistent across specifications.

Also for the compliance variables, the results are qualitatively the same. Banks that fail to report their scores on bank standards live shorter. Banks in violation with the capital adequacy standard tend to live shorter, although not always significant. The quick liquidity ratio and the current liquidity ratio seem to be enforced, but this is again not necessarily good news. We now find evidence of consistent enforcement of the bank standard on insider lending (N10.1), as we did in table 5B. Unfortunately we also confirm the earlier finding that the individuals' deposits to capital ratio (N11) is not properly enforced, quite on the contrary. More violations and more severe violations tend to increase bank survival, even significantly so for severe violations (see specifications $2 \mathrm{a}, 2 \mathrm{~b}$ and $2 \mathrm{c}$ ). In sum, we can again not reject the thesis that the CBR is very reluctant to withdraw licenses from banks that are very active on the deposit market, while there is some level of enforcement for most other bank standards. We interpret this as support for our thesis that the CBR suffers from a conflict between the objectives of individual bank safety and systemic stability. 


\section{Summary and conclusions}

In this paper we focus on the potential conflict between two central bank objectives, namely individual bank stability, that is usually assured through the enforcement of prudential bank standards, and systemic stability. We do this by empirically studying the licensing policy of the Central Bank of Russia (CBR) in the period 1999-2002. Russia provides an interesting example to analyze potential conflicts in the objective function of the central bank, because it has a very young central bank that combines a lot of authorities and functions. Equally important, there are many banks and many bank failures which allow us to study empirically how well the CBR enforces its own bank standards. We believe however that the fundamental issue, namely the possibility of conflict between individual bank stability and systemic bank stability in a central bank's objective function, is a fundamental one. Russia is simply the perfect country to measure it.

Our analysis found indeed indications of this conflict. Controlling for economic reasons of bank failure (loan quality, profitability, liquidity, efficiency, market power) we found that there are a number of biases in the CBR's licensing policy. Specifically banks in poorly banked regions, banks that are too big to be disciplined adequately and banks that are active on the interbank market seem to enjoy some protection against license withdrawal from the CBR, showing the CBR's concern for the banking system rather than individual banks. We also verify whether the CBR properly enforces its own prudential bank standards. It turns out that there has been some level of enforcement of the bank standards recently, but with one very important exception. The CBR turns out to be very reluctant to withdraw bank licenses from banks that repeatedly and severely violate the individuals' deposits to capital ratio. We interpret this as a clear indication of a conflict with the tacit CBR objective of securing depositor trust and systemic stability.

These results are a mixed bag for the Russian banking sector. The fact that bank survival depends strongly on economic fundamentals is positive news. The finding that most bank standards show some level of enforcement is unexpectedly positive. However, the fact that mainly liquidity regulations are being enforced is not really comforting. It suggests that the CBR is still running behind the facts, mainly de-licensing already illiquid banks (that are maybe illiquid because of asset stripping in the face of expected de-licensing) instead of anticipating future trouble. Furthermore, we find that tacit objectives in the CBR objective function are in conflict with some of the bank standards, which creates an unwelcome inconsistency and prohibits proper enforcement. The current economic growth has ensured that the Russian banking sector is now awash with liquidity. The 
CBR should use this window of opportunity and embark on a real restructuring and monitoring of the banking sector. This requires a clear statement from the CBR of its objectives, transparent formulation of prudential bank standards that are consistent with the stated objectives and enforcement of these standards by means of strong actions, ultimately closure. If not, the CBR's policy risks to loose credibility which will further postpone the emergence of a stable and sound banking sector in Russia.

\section{References}

Acharya, Sankarshan. (1996). "Charter value, minimum bank capital requirement and deposit insurance pricing in equilibrium". Journal of Banking and Finance 20, 351-75.

Alonso, Irasema. (1996). "On Avoiding Bank Runs." Journal of Monetary Economics 37, 73-87.

Aghion, Philippe, Patrick Bolton, and Steven Fries. (1999). "Optimal Design of Bank Bailouts: The Case of Transition Economies." Journal of Institutional and Theoretical Economics 155, 51-70.

Bagehot, Walter. (1873). Lombard Street: A Description of the Money Market. London: H.S. King.

Blum, Jürg. (1999). "Do capital adequacy requirements reduce risks in banking?" Journal of Banking and Finance 23, 755-771.

Boot, Arnoud W.A., and Anjan Thakor. (1993). "Self-interested bank regulator." American Economic Review, AEA Papers and Proceedings 83, 206-212.

Brana, Sophie, Mathilde Maurel, and Jerome Sgard. (1999). "Enterprise Adjustment and the Role of Bank Credit in Russia: Evidence from a 420 Firm's Qualitative Survey." CEPII Working Paper 1999/06, April 1999.

Calomiris, Charles W., and Joseph R. Mason. (2000). "Causes of U.S. Bank Distress during the depression." NBER Working Paper 7919, September 2000.

Champ, Bruce, Bruce D. Smith, and Stephen D. Williamson. (1996). "Currency Elasticity and Banking Panics: Theory and Evidence" Canadian Journal of Economics, 29, 828-64.

Chari, Varadarajan. (1989). "Banking without Deposit Insurance or Bank Panics: Lessons from a Model of the U.S. National Banking System." Federal Reserve Bank of Minneapolis Quarterly Review 13, 3-19.

Cordella, Tito, and Edwardo L. Yeyati. (2003). "Bank bailouts: moral hazard vs. value effect." Journal of Financial Intermediation 12, 300-330. 
Dewatripont, Mathias, and Jean Tirole. (1994). The Prudential Regulation of Banks. Cambridge, MIT Press.

Diamond, Douglas W., and Philip H. Dybvig. (1983). "Bank Runs, Deposit Insurance, and Liquidity." Journal of Political Economy 91, 401-19.

Di Noia, Carmine, and Giorgio Di Giorgio. (1999). "Should Banking Supervision and Monetary Policy Tasks be Given to Different Agencies?", International Finance 2, 361-78.

Freixas, Xavier, Bruno M. Parigi, and Jean-Charles Rochet. (2000). "Systemic Risk, Interbank Relations, and Liquidity Provision by the Central Bank." Journal of Money, Credit and Banking 32, Part 2: What Should Central Banks Do?, 611-638.

Goodhart, Charles. (1988). The Evolution of Central Banks. MIT Press, Cambridge, MA.

Goodhart, Charles. (1995). The Central Bank and the Financial System. MIT Press, Cambridge, MA.

Goodhart, Charles, and Haizhou Huang. (1999). "A model of lender of last resort." IMF Working Paper 99/39, International Monetary Fund, March 1999.

Heckman, James J., and Burton Singer. (1984). "A Method for minimizing the impact of distributional assumptions in econometric models for duration data." Econometrica 52, 271-320.

Heinemann, Friedrich, and Martin Schüler. "A Stiglerian View of Banking Supervision." Public Choice, forthcoming.

Kaminsky, Graciela L., and Carmen M. Reinhart. (1999). "The Twin Crises: The Causes of Banking and Balance-of-Payments Problems." American Economic Review 89, 473-500.

Kane, Edward. (2000). "Incentives for Banking Megamergers: What Motives Might Regulators Infer from Event-Study Evidence?" Journal of Money, Credit, and Banking 32, Part 2, 671-701.

Kapstein, Ethan B. (1994). Governing the global economy: International finance and the state. Cambridge and London, Harvard University Press.

Laeven, Luc. (2001). "Insider Lending and Bank Ownership, The case of Russia." Journal of Comparative Economics 29, 207-229.

Laffont, Jean-Jacques, and Jean Tirole. (1991). "The Politics of Government decision Making: a Theory of Regulatory Capture." Quarterly Journal of Economics 106, 1089-1127.

Mailath, George J., and Loretta J. Mester. (1994). "A Positive Analysis of Bank Closure." Journal of Financial Intermediation 3, 272-299.

Malyutina, Marina, and Svetlana Parilova. (2001). "The Determinants of Excessive RiskTaking by Banks in Transition." Economics Education and Research Consortium-Russia and CIS, 
2001.

Mizobata, Satoshi. (2002). "Bank sector restructuring." In Russian Banking, Evolution, Problems and Prospects, edited by David Lane, pp. 36-55. Edward Elgar Publishing, Cheltenham, UK.

OECD. (2004). "Economic Survey of the Russian Federation." Paris.

Peek, Joe, Eric S. Rosengren, and Geoffrey M. B. Tootell. (1999). "Is Bank Supervision Central to Central Banking?" Quarterly Journal of Economics 114, 629-53.

Perotti, Enrico. (2002). "Lessons from the Russian Meltdown, The economics of soft legal constraints." International Finance 5, 359-399.

Postlewaite, Andrew, and Xavier Vives. (1987). "Bank Runs as an Equilibrium Phenomenon." Journal of Political Economy 95, 485-91.

Povel, Paul. (1996). "Optimal 'soft' or 'tough' bankruptcy procedures." LSE Financial Market Group Discussion Paper 240, 1996.

Pyle, William. (2002). "Overbanked and credit-starved: A Paradox of the Transition." Journal of Comparative Economics 30, 25-50.

Repullo, Rafael. (2000). "Who Should Act as Lender of Last Resort? An incomplete Contracts Model." Journal of Money, Credit and Banking 32, Part 2: What should Central Banks Do?, 580-605.

Rochet, Jean-Charles, and Jean Tirole. (1996). "Interbank Lending and Systemic Risk." Journal of Money, Credit and Banking, 28, Part 2, 733-762.

Schoors, Koen. (1999). "The Mired Restructuring of Russia's Banking System." Russian Economic Trends 4, 35-45.

Schoors, Koen. (2001). "The Credit Squeeze during Russia's Early Transition, A bank-based view." Economics of Transition 9, 205-228.

Schoors, Koen. (2003). "The fate of Russia's former state banks: Chronicle of a restructuring postponed and a crisis foretold." Europe-Asia Studies 55, 75-100.

Schoors, Koen, and Konstantin Sonin. "Passive Creditors." International Finance, forthcoming.

Sleet, Christopher, and Bruce D. Smith. (2000). "Deposit Insurance and Lender-of-Last-Resort Functions." Journal of Money, Credit and Banking 32, Part 2: What should Central Banks Do?, 518-575.

Tompson, William. (2002). "The present and future of banking reform." In Russian Banking, Evolution, Problems and Prospects, edited by David Lane, pp. 56-78. Edward Elgar Publishing, 
Cheltenham, UK.

Tompson, William. (2004). "Banking reform in Russia: Problems and Prospects." OECD Economics Working Paper 410, November 2004.

Wall, Larry D., and David R. Peterson. (1990). "The effect of Continental Illinois' failure on the financial performance of other banks." Journal of Monetary Economics 26, 77-99.

Wallace, Neil. (1990). "A Banking Model in Which Partial Suspension Is Best." Federal Reserve Bank of Minneapolis Quarterly Review 14, 11-23. 


\section{A Data sources}

The bank data were supplied, though not exactly for free, by two well established Russian information agencies, INTERFAKS and MOBILE, and by the CBR. INTERFAKS supplied a database with quarterly bank data on balances, profit and loss accounts and quarter-specific, bank-specific scores on a battery of regulatory standards for all Russian banks from 1999 to 2002. MOBILE provided monthly bank balances and profit and loss accounts and a more limited list of quarter-specific, bank-specific scores on regulatory standards but for a longer period, from mid 1995 (although initially not for all banks) up till 2002. The two databases complement because they offer different classifications and different levels of detail of the same data. The financial data employed in the analysis includes almost 1400 banks, i.e. all operational banks in the period under study, covering 16 quarters from 1999:Q1 to 2002:Q4. These financial data were linked to bank licensing data. From the freely available information on the CBR's website we reconstructed the complete register of bank licenses. The dataset contains bank license data of all banks from 1988 up till now. For every bank that ever existed in Russia, we know when it received a licence, what type of license it exactly received, when it lost the license if ever and what was the official reason for losing it. We also know from the CBR instructions and regulations how the supervisory standards evolved in the period under study. So for every bank in every period we know how the bank should score on a specific standard and how it actually does, which allows the identification of breaches of regulatory standards. For a very detailed overview on all data issues, please consult Karas and Schoors on www.ceriseonline.be.

\section{B Prudential regulations of the CBR}

The regulation that governs our period of study came into force on April 1, 1996 and draws on the CBR Instruction No. 1 of January 30, 1996, "On the Procedure for Regulating the Activities of Credit Organisations" ${ }^{18}$. This regulation is issued in accordance with the Federal Law on the Central Bank of the Russian Federation (Bank of Russia) and established a set of new prudential bank standards, taking into account international banking practices. To Russian standards the new bank standards were rather harsh and the CBR gave banks time to adjust to the new conditions. Yet the enormous peak of license withdrawals in May 1996 (see figure 6) demonstrates that the

\footnotetext{
${ }^{18}$ For more information on regulation we refer to the references for banking legislation described at the end of the appendix.
} 
adjustment process was not too gradual either. We concentrate on the bank standards or 'normas' (as the CBR refers to them) imposed by the CBR. Next to minimal capital requirements the CBR installed capital adequacy requirements (N1), liquidity requirements (N2, N3, N4, N5), credit risk requirements (N7, N9, N10, N11, N12, N13), and a host of other less important (and often non-compulsory) regulations:

\section{B.1 Capital adequacy ratio (N1)}

From April 1, 1996, the bank equity capital adequacy ratio (N1) was established as the ratio of the bank's equity capital to the overall risk-weighted assets minus the sum of the reserves created for depreciation of securities and possible losses. Since February 1998, the minimum level of N1 is set depending on the amount of the bank's equity capital:

\begin{tabular}{lcc}
\hline 5 million euro & 1 to 5 million euro & Less than 1 million euro \\
\hline \multicolumn{3}{c}{ July, 1996-5\% } \\
\hline & February, 1997-6\% \\
\hline February, 1998-7\% & February, 1998-7\% & February, 1998-7\% \\
February, 1999-8\% & February, 1999-9\% \\
January, 2000-10\% & January, 2000-11\% \\
\hline
\end{tabular}

\section{B.2 Instant liquidity ratio (N2)}

$\mathrm{N} 2$ is defined as the ratio of the sum of the bank's highly liquid assets to the sum of the bank's liabilities on demand accounts. The minimum value of the N2 ratio was set at $10 \%$ since July 1 , 1996 and 20\% since February 1, 1997.

\section{B.3 Current liquidity ratio (N3)}

The current liquidity ratio (N3) was established as the ratio of the sum of the bank's liquid assets to the sum of the bank's liabilities on demand accounts and accounts up to 30 days. The minimum value of the current liquidity ratio was set at no less than:

$20 \%$ of total assets as of July 1, 1996;

$30 \%$ of total assets as of February 1, 1997;

$50 \%$ of total assets as of February 1, 1998;

$70 \%$ of the balance as of February 1, 1999. 


\section{B.4 Long-term liquidity ratio (N4)}

The long-term liquidity ratio (N4) is established as the ratio of the entire long-term debt to the bank, including guarantees and sureties with a maturity of more than one year, to the bank's equity capital and liabilities on deposit accounts, credits received and other debt liabilities with maturities exceeding one year. The long-term liquidity ratio should not exceed $120 \%$.

\section{B.5 General liquidity ratio (N5)}

The general liquidity ratio is defined as the percentage of liquid assets in the bank's aggregate assets. The minimum value of the N5 ratio has been set at:

$10 \%$ of total assets as of July 1, 1996;

$20 \%$ of total assets as of February 1, 1997.

\section{B.6 Maximum large credit risk (N7)}

The maximum large credit risk (N7) is established as a percentage of the total amount of large credit risks in the bank's equity capital. A large credit is the total sum of the bank's risk-weighted claims to one borrower (or a group of related borrowers) on credits, taking into account $50 \%$ of the sum of off-balance claims - guarantees and sureties held by the bank with regard to one borrower (or a group of related borrowers), exceeding $5 \%$ of the bank's equity capital. Note that the decision to extend such a large credit or loan must be made by the board of the bank or its credit committee, taking into account the opinion of the bank's credit department. Maximum large credit risk should not exceed the bank's capital by more than 12 times in 1996, 10 times in 1997 and 8 times in 1998.

\section{B.7 Maximum risk per borrower-shareholder (N9.1)}

The maximum risk per borrower-shareholder (partner) (N9.1) is established as the amount of credits, guarantees and sureties issued by the bank to one corporate or individual shareholder (partner) or to a group of related corporate or individual shareholders of the bank divided by equity capital. Related shareholders are corporate and individual shareholders connected with one another economically and legally (i.e., having common property and/or mutual guarantees and/or obligations, and/or controlling each other's property and also an individual concurrently holding several senior executive positions) in such a way that the financial problems of one of the 
shareholders cause or may cause financial problems for another shareholder(s). N9.1 should not exceed $50 \%$ of the bank's equity capital from January 1, 1998.

\section{B.8 Maximum credit to insiders (N10.1)}

The aggregate amount of credits and loans extended to insiders (N10.1) may not exceed 3\% of the bank's equity capital. Insiders comprise the following individuals: shareholders who own more than $5 \%$ of shares, directors (presidents, chairmen and their deputies), Board members, members of the credit committee, senior executives of subsidiary and parent structures and other persons who may influence the decision to issue credit, and also relatives of insiders, former insiders and other persons participating in outside structures, in which insiders participate as well.

\section{B.9 Minimal coverage of household deposits by capital (N11)}

N11 is established as the ratio of the sum of household deposits to equity capital. Since July 1996, household deposits should be $100 \%$ covered by equity capital.

\section{B.10 Minimal coverage of the bank's investments in shares by capital (N12)}

The bank's own investments in shares of other legal entities has been limited to:

$45 \%$ of equity capital as of July 1, 1996;

$35 \%$ of equity capital as of October 1, 1996;

$25 \%$ of equity capital as of January 1, 1997.

\section{B.11 Bank's own promissory note liability risk ratio (N13)}

N13 is established as the percentage of the bills of exchange and bills of acceptance issued by the bank plus $50 \%$ of the bank's off-balance liabilities arising from the endorsement of bills, sureties and bill brokerage in the bank's equity capital. The maximum levels have been set at:

$200 \%$ of the balance as of October 1, 1996;

$100 \%$ of the balance as of March 1, 1997.

\section{B.12 References for banking legislation}

Federal Law of December 2, 1990, No. 395-1, "On Banks and Banking Activity". 
Instruction No.1 of May 5, 1991, "On the Procedure of Regulating the Activities of Credit Organisations".

Bank of Russia Instruction No.1 of January 30, 1996, "On the Procedure of Regulating the Activities of Credit Organisations" of May 5,1991.

Civil Code of Russian Federation, part I.

Bank of Russia Instruction No.59 of March 31, 1997, "On Imposing Sanctions to Credit Organizations for Infringement of Prudential Norms".

Bank of Russia Letter No.121-T of August 20, 2003 "About actions which should be taken when facts of breaching norms N8, N9, N11, N11.1 and N14 are revealed".

Bank of Russia Letter No.124-T of August 21, 2003 "On the bank's own promissory note liability risk ratio N13". 


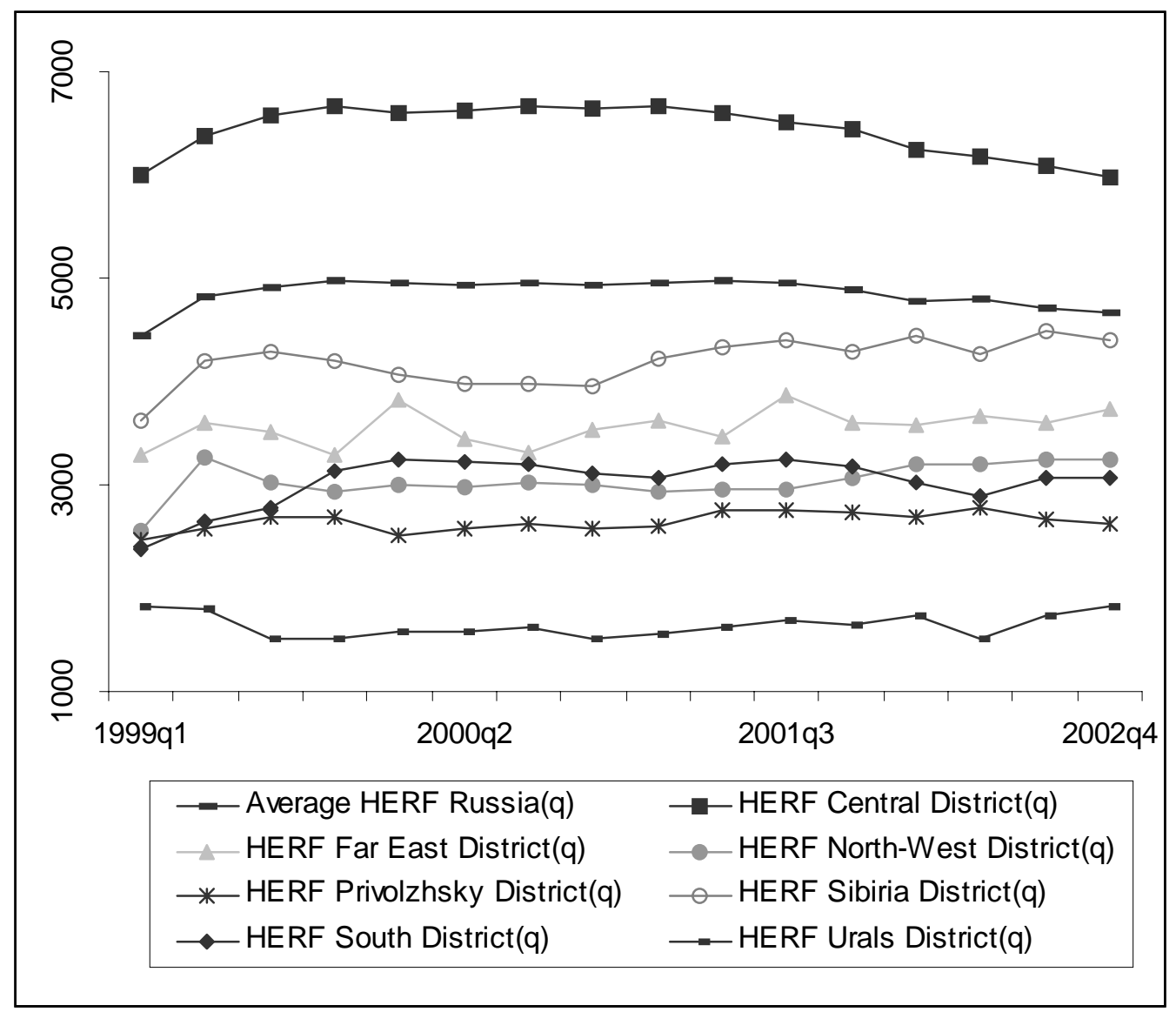

Figure 1: Herfindahl indices (deposits) for several federal districts within Russia (quarterly, 19992002). Source: Own calculations based on INTERFAX data. 


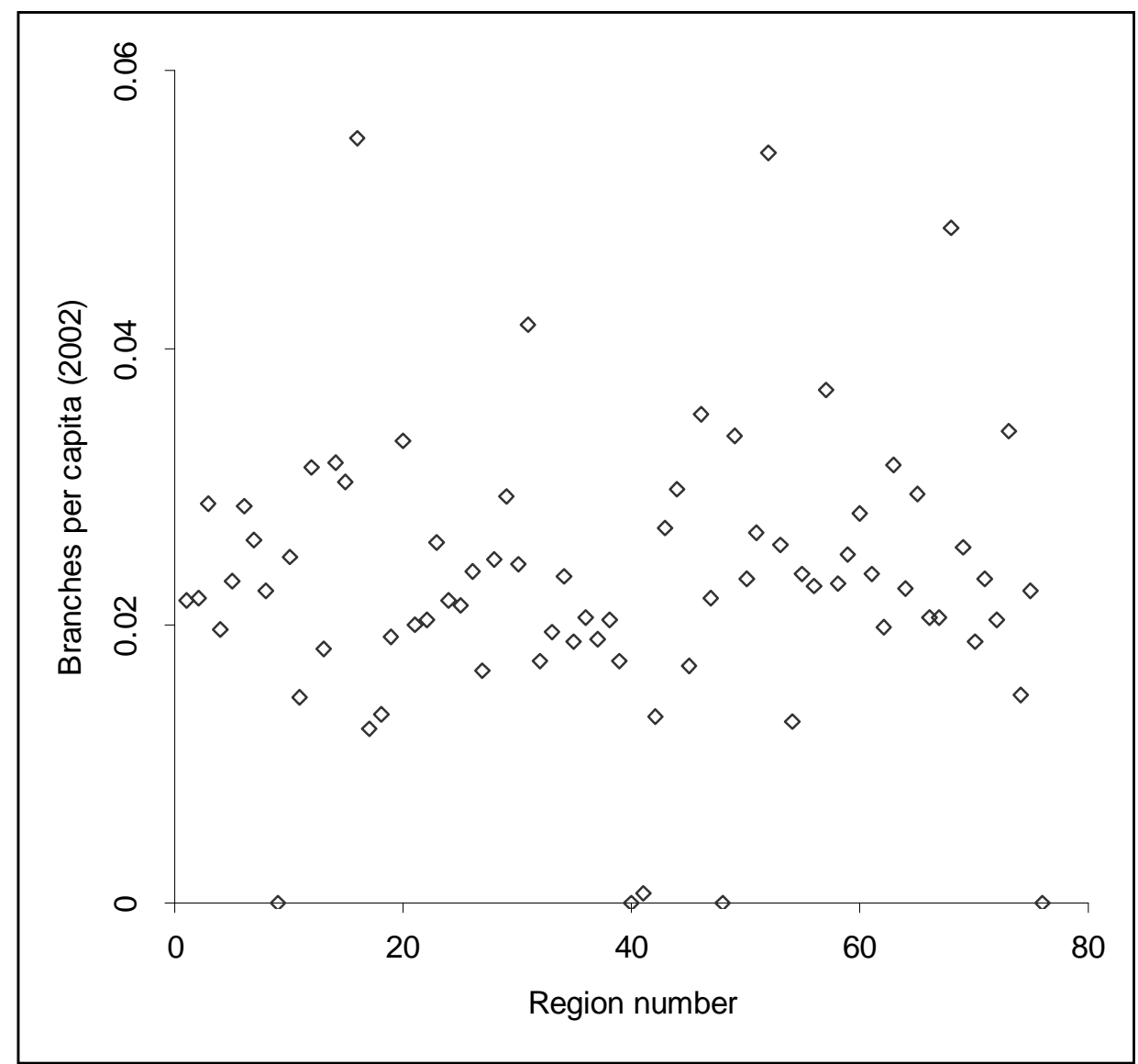

Figure 2: Bank branches per capita (2002). Source: own calculations based on data from the CBR (bank branches per region) and Goskomstat (population expressed in thousands). 


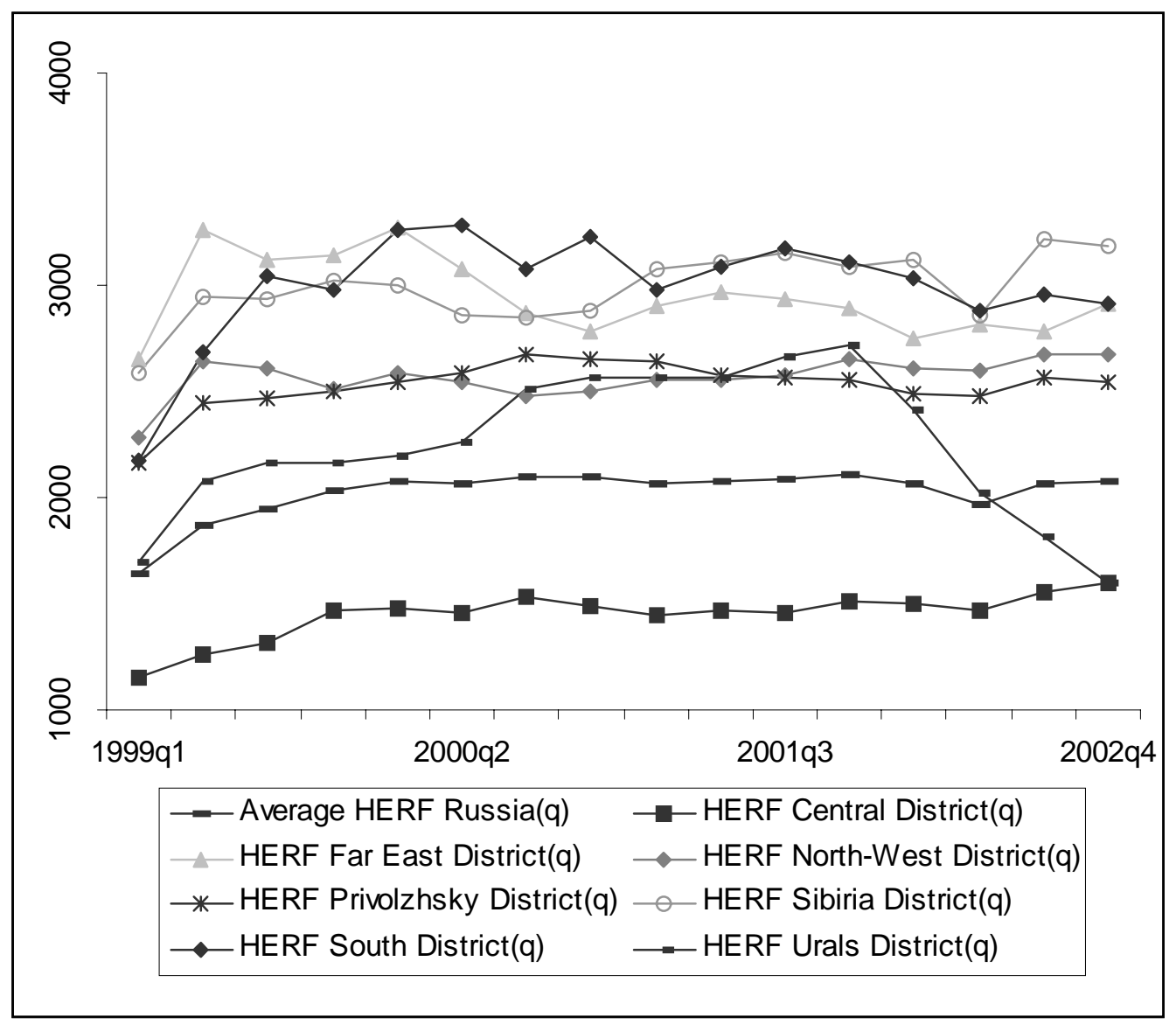

Figure 3: Herfindahl indices (assets) for several federal districts within Russia (quarterly, 19992002). Source: Own calculations based on INTERFAX data. 


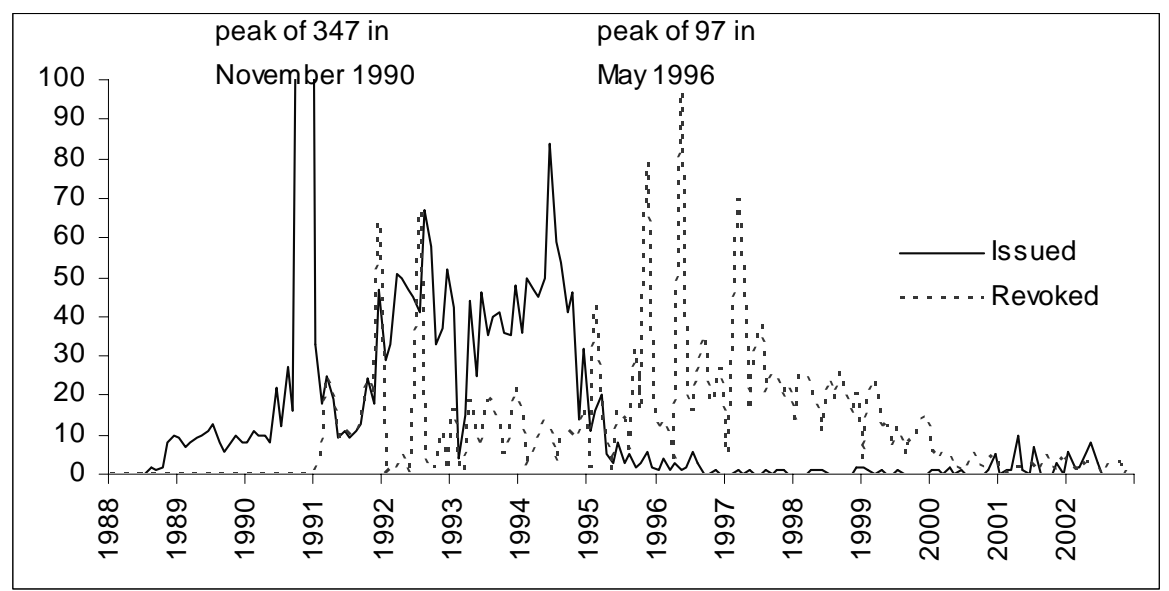

Figure 4: Bank creation and bank destruction in Russia (monthly data). Bank creation is defined as the number of licenses issued; bank destruction is defined as the number of license withdrawals. Source: CBR.
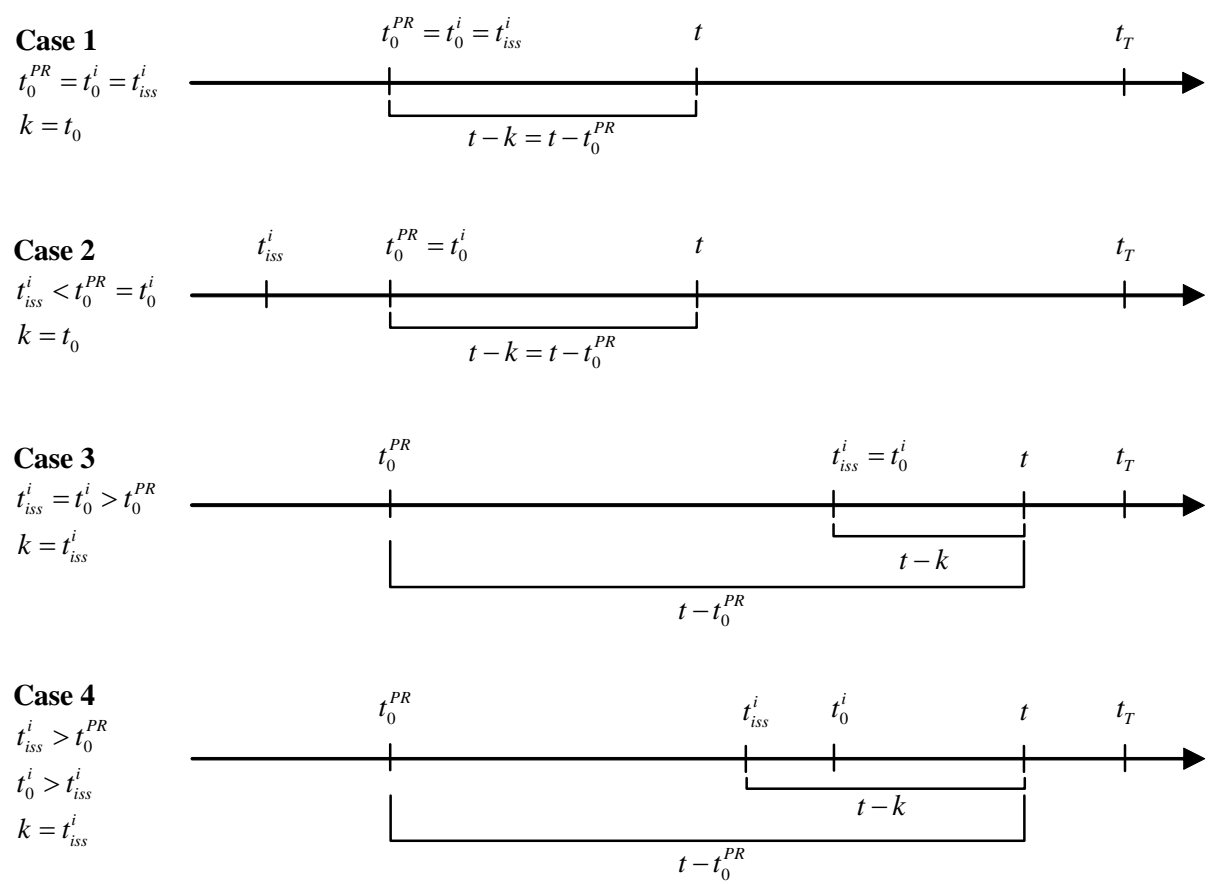

Figure 5: $t_{0}^{P R}$ marks the first quarter in which we observe bank-specific scores on different regulations; $t_{T}$ marks the end of our sample (2002.4); $t_{i s s}^{i}$ marks the quarter in which bank $i$ 's license was issued; $t_{0}^{i}$ marks the first observation of bank $i$; $t_{T}-t_{0}^{P R}$ marks the sample period for observing bank standards; $t-k$ is the number of potential breaches; $t-t_{0}^{P R}$ is the number of quarters used to correct for 'late entry' or 'late license issuance'. 
TABLE 1

Description of Variables and Data Sources

Deflator $^{1}$

Moscow Dummy

\section{Economic Variables}

Return on assets ${ }^{2}$

Cost/ assets $^{2}$

Interbank liabilities/liabilities ${ }^{2}$ Regional market share (assets) ${ }^{2}$

Non performing loans/loans ${ }^{2}$ Reserves/assets ${ }^{2}$

\section{Tacit CBR Objectives}

Regional Herfindahl (assets) ${ }^{2}$

Size (log assets) ${ }^{2}$

Interbank market share (money centre banks) $^{2}$

Government claims/assets ${ }^{2}$ Government portfolio share ${ }^{2}$

Average monthly inflation (\%).

A dummy variable which equals one if the bank is located in Moscow, zero otherwise.

The returns-to-assets ratio of bank $i$ in quarter $t(\%)$.

The ratio of personnel costs to two month average of total assets of bank $i$ in quarter $t(\%)$.

Interbank liabilities to total liabilities of bank $i$ in quarter $t(\%)$.

The regional ${ }^{4}$ market share in assets, calculated as the ratio of bank $i$ 's individual assets to the sum of bank assets for region $j$ in quarter $t$ (between 0 and 100).

The ratio of non-performing loans to total loans of bank $i$ in quarter $t(\%)$. The ratio of total reserves (including excess reserves) to total assets of bank $i$ in quarter $t(\%)$.

The regional ${ }^{4}$ Herfindahl index, calculated as the sum of squared regional market shares for each region $j$ in quarter $t$ (between 0 and 1000).

The $\log$ of assets of bank $i$ in quarter $t$.

The share of interbank liabilities of bank $i$ 's individual interbank liabilities to the country total in quarter $t(\%)$.

The ratio of government claims to assets of bank $i$ in quarter $t(\%)$.

The share of bank $i$ 's individual government claims to the country total in quarter $t(\%)$.

\section{Compliance with Regulatory Standards ${ }^{3}$}

Non-reported scores

breach $_{n, i, t}$

nbreach $_{n, i, t}$

dnbreach $_{n, i, t}$

sbreach $_{n, i, t}$

dsbreach $_{n, i, t}$

vbreach $_{n, i, t}$
A dummy variable which equals one when information on regulatory standards 7, 9.1, 10.1, 11, 12 and 13 is not reported and zero otherwise. A dummy variable which equals one whenever bank $i$ violates regulation $n$ in quarter $t$, zero otherwise.

The sum of actual breaches -relative to the maximum potentialregistered by bank $i$ from $t_{0}^{P R}$ up till $t$, corrected for 'late entry' (see Figure 5).

An exponentially smoothed version of nbreach with varying weights for $\alpha$. The average severity of breaches registered by bank $i$ from $t_{0}^{P R}$ up till $t$. Severity is defined as the relative deviation from the prudential standard whenever breach equals one.

An exponentially smoothed version of sbreach with varying weights for $\alpha$. The product of nbreach and sbreach of bank $i$ in quarter $t$.

${ }^{1}$ Source: Russian Economic Trends. ${ }^{2}$ Source: Own calculations based on Interfaks. ${ }^{3}$ Source: Own calculations based on regulatory standards published by the CBR (see Appendix B) and bank-specific scores on regulatory standards acquired from Interfaks and Mobile. ${ }^{4}$ Note: We use 80 regions for the calculation of regional market shares. 
TABLE $2 \mathrm{a}$

Summary Statistics: Economic Variables

\begin{tabular}{|c|c|c|c|c|c|}
\hline & Obs & Mean & Std. Dev. & Min & Max \\
\hline Deflator & 20840 & 1.97 & 1.75 & 0.46 & 8.02 \\
\hline Moscow Dummy & 20840 & 0.48 & 0.50 & 0 & 1 \\
\hline \multicolumn{6}{|l|}{ Economic Variables } \\
\hline Return on assets & 20730 & 0.58 & 8.18 & -149.61 & 479.61 \\
\hline Cost/assets & 20807 & 1.30 & 2.16 & 0 & 76.60 \\
\hline Interbank liabilities/liabilities & 20801 & 10.66 & 19.19 & 0 & 100 \\
\hline Regional market share (assets) & 20840 & 5.75 & 13.97 & 0 & 100 \\
\hline Non performing loans/loans & 20387 & 5.06 & 12.96 & 0 & 100 \\
\hline Reserves/assets & 20840 & 17.63 & 15.49 & 0 & 100 \\
\hline \multicolumn{6}{|l|}{ Tacit CBR Objectives } \\
\hline Regional Herfindahl (assets) & 20840 & 1746 & 1302 & 399 & 8955 \\
\hline Size (log assets) & 20840 & 4.92 & 1.95 & -1.94 & 11.75 \\
\hline $\begin{array}{l}\text { Interbank market share } \\
\qquad \text { (money centre banks) }\end{array}$ & 20840 & 0.08 & 0.54 & 0 & 16.78 \\
\hline Government claims/assets & 20840 & 1.91 & 6.50 & 0 & 100 \\
\hline Government portfolio share & 20840 & 0.08 & 0.85 & 0 & 35.65 \\
\hline
\end{tabular}

Source: Own calculations based on Interfaks, Russian Economic Trends and CBR. Detailed information on variable definitions is provided in Table 1. 
TABLE $2 b$

Summary Statistics: Compliance with Regulatory Standards

\begin{tabular}{|c|c|c|c|c|c|}
\hline & Obs & Mean & Std. Dev. & Min & Max \\
\hline \multirow[t]{2}{*}{ Non-reported scores } & 20840 & 0.07 & 0.25 & 0 & 1 \\
\hline & \multicolumn{5}{|c|}{ Number of Breaches } \\
\hline Capital adequacy ratio (N1) & 20503 & 0.53 & 1.66 & 0 & 21 \\
\hline Quick liquidity ratio (N2) & 20493 & 0.74 & 1.89 & 0 & 16 \\
\hline Current liquidity ratio (N3) & 20494 & 1.06 & 2.14 & 0 & 17 \\
\hline Long-term liquidity ratio (N4) & 20492 & 0.13 & 0.66 & 0 & 11 \\
\hline General liquidity ratio (N5) & 20500 & 1.10 & 2.48 & 0 & 20 \\
\hline Large-risks-to-capital ratio (N7) & 20493 & 0.07 & 0.41 & 0 & 6 \\
\hline Owner-related-credit-risks-to-capital ratio (N9.1) & 20491 & 0.19 & 0.64 & 0 & 6 \\
\hline Insider-related-credit-risks-to-capital ratio (N10.1) & 20492 & 0.16 & 0.63 & 0 & 9 \\
\hline Individuals' deposits-to-capital ratio (N11) & 20491 & 1.54 & 3.37 & 0 & 22 \\
\hline Investment-to-shares-to-capital ratio (N12) & 20491 & 0.16 & 0.60 & 0 & 8 \\
\hline \multirow[t]{2}{*}{ Issued-promissory-notes-to-capital ratio (N13) } & 20492 & 0.35 & 1.18 & 0 & 16 \\
\hline & \multicolumn{5}{|c|}{ Severity of Breach } \\
\hline Capital adequacy ratio (N1) & 20488 & 0.19 & 2.03 & 0 & 59.12 \\
\hline Quick liquidity ratio (N2) & 20473 & 0.15 & 0.79 & 0 & 13.98 \\
\hline Current liquidity ratio (N3) & 20491 & 0.14 & 0.95 & 0 & 26.38 \\
\hline Long-term liquidity ratio (N4) & 20433 & 0.01 & 0.09 & 0 & 1.82 \\
\hline General liquidity ratio (N5) & 20481 & 0.05 & 0.16 & 0 & 2.70 \\
\hline Large-risks-to-capital ratio (N7) & 20401 & 0.00 & 0.02 & 0 & 0.50 \\
\hline Owner-related-credit-risks-to-capital ratio (N9.1) & 20440 & 0.03 & 0.18 & 0 & 4.18 \\
\hline Insider-related-credit-risks-to-capital ratio (N10.1) & 20407 & 0.05 & 0.41 & 0 & 16.44 \\
\hline Individuals' deposits-to-capital ratio (N11) & 20462 & 0.13 & 0.55 & 0 & 8.67 \\
\hline Investment-to-shares-to-capital ratio (N12) & 20473 & 0.03 & 0.20 & 0 & 4.35 \\
\hline \multirow[t]{2}{*}{ Issued-promissory-notes-to-capital ratio (N13) } & 20452 & 0.05 & 0.29 & 0 & 5.66 \\
\hline & \multicolumn{5}{|c|}{ Volume of Breach } \\
\hline Capital adequacy ratio (N1) & 20387 & 0.35 & 3.20 & 0 & 99.40 \\
\hline Quick liquidity ratio (N2) & 20441 & 0.75 & 4.76 & 0 & 81.52 \\
\hline Current liquidity ratio (N3) & 20477 & 0.83 & 5.79 & 0 & 99.99 \\
\hline Long-term liquidity ratio (N4) & 20424 & 0.03 & 0.26 & 0 & 5.11 \\
\hline General liquidity ratio (N5) & 20442 & 0.34 & 1.36 & 0 & 15.33 \\
\hline Large-risks-to-capital ratio (N7) & 20401 & 0.00 & 0.04 & 0 & 0.65 \\
\hline Owner-related-credit-risks-to-capital ratio (N9.1) & 20435 & 0.06 & 0.43 & 0 & 9.13 \\
\hline Insider-related-credit-risks-to-capital ratio (N10.1) & 20407 & 0.13 & 1.29 & 0 & 40.95 \\
\hline Individuals' deposits-to-capital ratio (N11) & 20420 & 0.85 & 3.49 & 0 & 50.58 \\
\hline Investment-to-shares-to-capital ratio (N12) & 20462 & 0.07 & 0.56 & 0 & 11.85 \\
\hline Issued-promissory-notes-to-capital ratio (N13) & 20426 & 0.16 & 1.18 & 0 & 26.97 \\
\hline
\end{tabular}

Source: Own calculations based on Interfaks, Mobile and CBR. Note: The calculations of the compliance variables are based on the period 1997:Q2 - 2002:Q4. The estimation sample is restricted to the period 1999:Q1 - 2002:Q4. More detailed information on variable construction is provided in Table 1. Detailed information on regulatory standards is provided in appendix. 


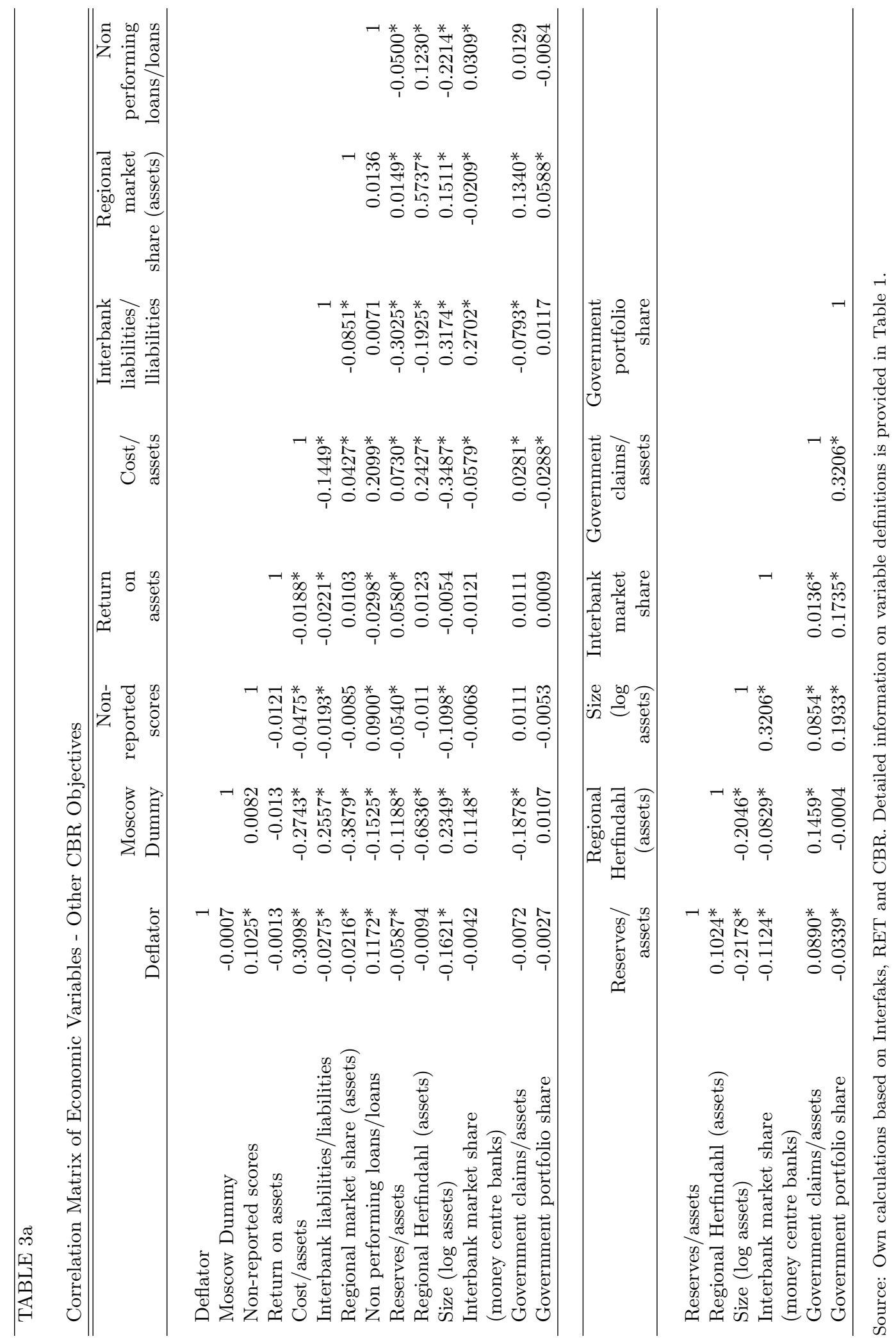




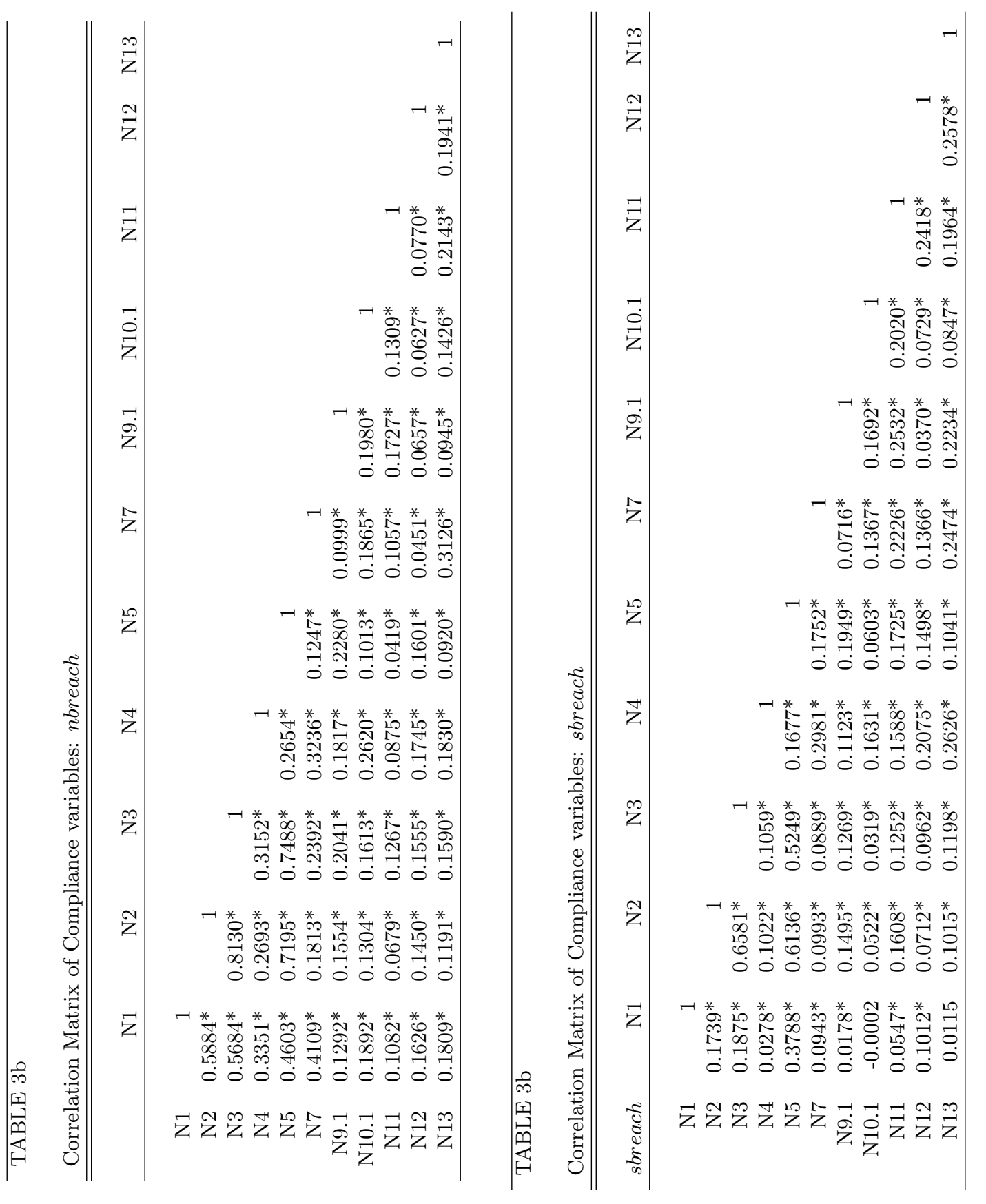




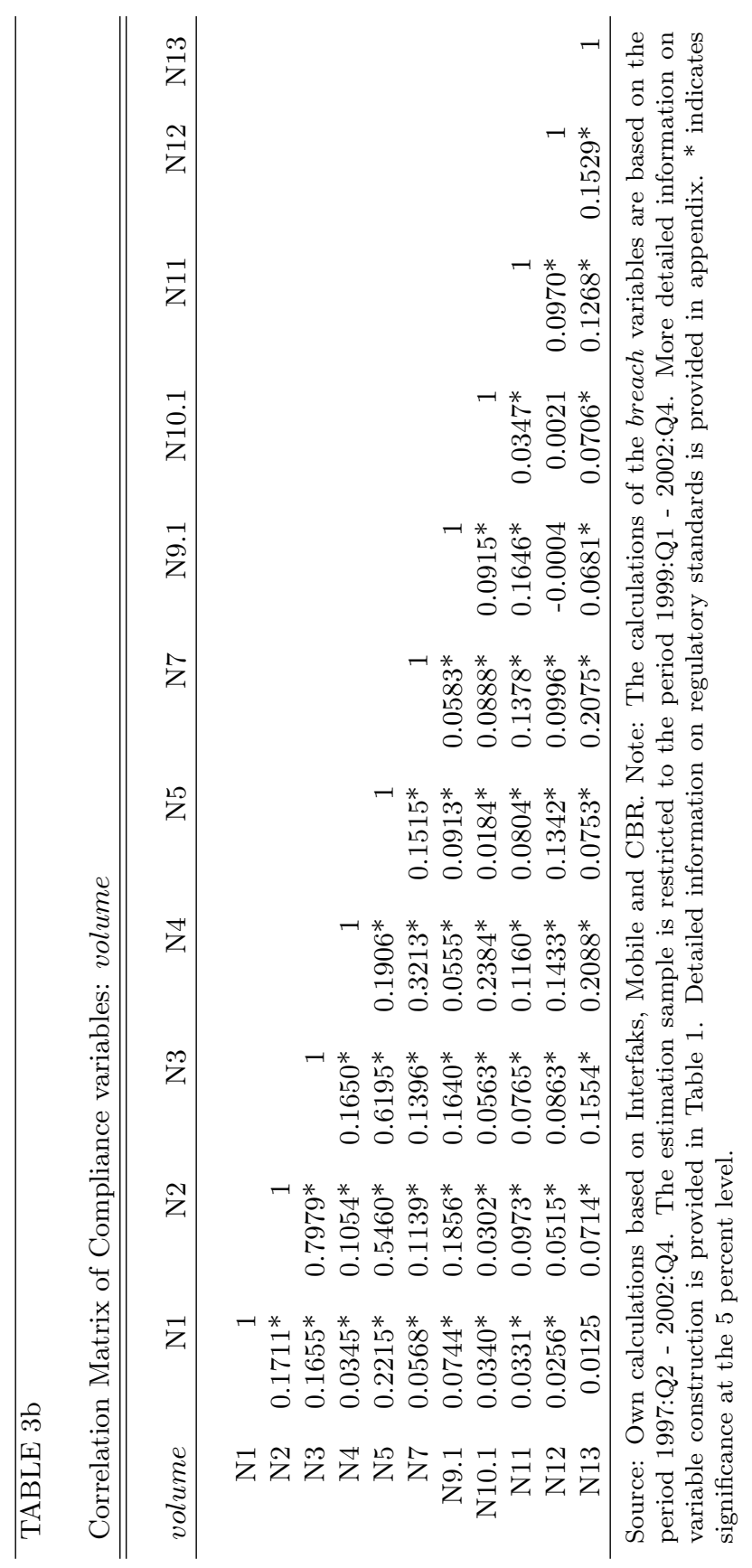


TABLE 4

Descriptive statistics

\begin{tabular}{|c|c|c|}
\hline Analysis time & \multicolumn{2}{|c|}{$\begin{array}{c}\text { In Sample of Estimation } \\
\text { 1999:Q1 - 2002:Q4 }\end{array}$} \\
\hline No. of banks & \multicolumn{2}{|c|}{1509} \\
\hline No. of failures & \multicolumn{2}{|c|}{226} \\
\hline Reason of Failure & Percent & Cum. \\
\hline Violation of bank legislation & 25.23 & 25.23 \\
\hline Compulsory Bankruptcy & 53.47 & 78.7 \\
\hline Voluntary bankruptcy & & \\
\hline Voluntary liquidation & 3.66 & 82.36 \\
\hline Merger & 17.64 & 100 \\
\hline
\end{tabular}

Source: Own calculations based on CBR. Note: The calculations of the compliance variables are based on the period 1997:Q2 - 2002:Q4. The estimation sample is restricted to the period 1999:Q1 - 2002:Q4. More detailed information on variable construction is provided in Table 1. Detailed information on regulatory standards is provided in appendix. 


\begin{tabular}{|c|c|c|c|c|c|c|}
\hline \multicolumn{7}{|c|}{ 1 Results for the Logit Model } \\
\hline & $\begin{array}{c}\text { (1) } \\
\text { nbreach }\end{array}$ & $\begin{array}{l}\text { (2) } \\
\text { sbreach }\end{array}$ & $\begin{array}{l}\text { (3) } \\
\text { vbreach }\end{array}$ & $\begin{array}{l}\text { (4) } \\
\text { nbreach }\end{array}$ & $\begin{array}{c}(5) \\
\text { sbreach }\end{array}$ & $\begin{array}{c}(6) \\
\text { vbreach }\end{array}$ \\
\hline & \multicolumn{3}{|c|}{ Merger Excluded } & \multicolumn{3}{|c|}{ Merger Included } \\
\hline Constant & $\begin{array}{c}-4.0066^{* * *} \\
{[0.7937]}\end{array}$ & $\begin{array}{c}-3.1001^{* * *} \\
{[0.5546]}\end{array}$ & $\begin{array}{c}-3.3791 * * * \\
{[0.5762]}\end{array}$ & $\begin{array}{c}-7.4230^{* * *} \\
{[1.0699]}\end{array}$ & $\begin{array}{c}-3.2379^{* * *} * \\
{[0.4875]}\end{array}$ & $\begin{array}{c}-3.4072^{* * *} \\
{[0.5171]}\end{array}$ \\
\hline Deflator & $\begin{array}{l}-0.0588 \\
{[0.0700]}\end{array}$ & $\begin{array}{l}-0.0273 \\
{[0.0508]}\end{array}$ & $\begin{array}{l}-0.0237 \\
{[0.0522]}\end{array}$ & $\begin{array}{c}-0.3853^{* * *} * \\
{[0.1187]}\end{array}$ & $\begin{array}{c}0.01 \\
{[0.0453]}\end{array}$ & $\begin{array}{c}0.0068 \\
{[0.0474]}\end{array}$ \\
\hline Moscow Dummy & $\begin{array}{c}0.2892 \\
{[0.4317]}\end{array}$ & $\begin{array}{c}0.1633 \\
{[0.3208]}\end{array}$ & $\begin{array}{c}0.3086 \\
{[0.3331]}\end{array}$ & $\begin{array}{l}-0.3431 \\
{[0.5495]}\end{array}$ & $\begin{array}{c}-0.086 \\
{[0.2714]}\end{array}$ & $\begin{array}{l}-0.0008 \\
{[0.2850]}\end{array}$ \\
\hline Economic Variables & & & & & & \\
\hline Return on assets & $\begin{array}{c}-0.0159^{* *} \\
{[0.0065]}\end{array}$ & $\begin{array}{c}-0.0171^{* * *} \\
{[0.0060]}\end{array}$ & $\begin{array}{c}-0.0181 * * * \\
{[0.0061]}\end{array}$ & $\begin{array}{l}-0.0051 \\
{[0.0040]}\end{array}$ & $\begin{array}{c}-0.0099^{*} \\
{[0.0059]}\end{array}$ & $\begin{array}{c}-0.0103^{*} \\
{[0.0060]}\end{array}$ \\
\hline Cost/assets & $\begin{array}{c}0.1439 * * * \\
{[0.0338]}\end{array}$ & $\begin{array}{c}0.1206^{* * *} \\
{[0.0240]}\end{array}$ & $\begin{array}{c}0.1300^{* * *} \\
{[0.0254]}\end{array}$ & $\begin{array}{c}0.2230^{* * *} \\
{[0.0529]}\end{array}$ & $\begin{array}{c}0.1026^{* * *} \\
{[0.0227]}\end{array}$ & $\begin{array}{c}0.1099 * * * \\
{[0.0242]}\end{array}$ \\
\hline Interbank liabilities/liabilities & $\begin{array}{c}-0.0131^{* *} \\
{[0.0060]}\end{array}$ & $\begin{array}{l}-0.0053 \\
{[0.0049]}\end{array}$ & $\begin{array}{l}-0.0052 \\
{[0.0050]}\end{array}$ & $\begin{array}{c}-0.0129^{*} \\
{[0.0076]}\end{array}$ & $\begin{array}{c}0.0006 \\
{[0.0043]}\end{array}$ & $\begin{array}{c}0.0016 \\
{[0.0044]}\end{array}$ \\
\hline Regional market share(assets) & $\begin{array}{l}-0.0083 \\
{[0.0194]}\end{array}$ & $\begin{array}{l}-0.0039 \\
{[0.0174]}\end{array}$ & $\begin{array}{c}0.0114 \\
{[0.0175]}\end{array}$ & $\begin{array}{c}0.0142 \\
{[0.0372]}\end{array}$ & $\begin{array}{c}0.0071 \\
{[0.0124]}\end{array}$ & $\begin{array}{c}0.0166 \\
{[0.0125]}\end{array}$ \\
\hline Non performing loans/loans & $\begin{array}{c}0.0308^{* * * *} \\
{[0.0059]}\end{array}$ & $\begin{array}{c}0.0233^{* * * *} \\
{[0.0046]}\end{array}$ & $\begin{array}{c}0.0279 * * * \\
{[0.0050]}\end{array}$ & $\begin{array}{c}0.0533^{* * * *} \\
{[0.0083]}\end{array}$ & $\begin{array}{c}0.0216 * * * \\
{[0.0044]}\end{array}$ & $\begin{array}{c}0.0265 * * * \\
{[0.0049]}\end{array}$ \\
\hline Reserves/assets & $\begin{array}{c}-0.1253^{* * *} \\
{[0.0190]}\end{array}$ & $\begin{array}{c}-0.1263^{* * *} * \\
{[0.0178]}\end{array}$ & $\begin{array}{c}-0.1306^{* * *} \\
{[0.0184]}\end{array}$ & $\begin{array}{c}-0.0669 * * * \\
{[0.0146]}\end{array}$ & $\begin{array}{c}-0.0778^{* * *} * \\
{[0.0120]}\end{array}$ & $\begin{array}{c}-0.0800^{* * *} \\
{[0.0124]}\end{array}$ \\
\hline Tacit CBR Objectives & & & & & & \\
\hline Regional Herfindahl (assets) & $\begin{array}{c}-0.0009^{* * *} * \\
{[0.0002]}\end{array}$ & $\begin{array}{c}-0.0008^{* * *} \\
{[0.0002]}\end{array}$ & $\begin{array}{c}-0.0008^{* * *} \\
{[0.0002]}\end{array}$ & $\begin{array}{c}-0.0015^{* * *} \\
{[0.0003]}\end{array}$ & $\begin{array}{c}-0.0006^{* * *} \\
{[0.0002]}\end{array}$ & $\begin{array}{c}-0.0007^{* * *} \\
{[0.0002]}\end{array}$ \\
\hline Size (log assets) & $\begin{array}{c}-0.2068^{* * *} * \\
{[0.0783]}\end{array}$ & $\begin{array}{c}-0.1329^{* *} \\
{[0.0614]}\end{array}$ & $\begin{array}{c}-0.1318^{* *} \\
{[0.0641]}\end{array}$ & $\begin{array}{l}-0.1523 \\
{[0.0992]}\end{array}$ & $\begin{array}{c}-0.1493^{* * *} * \\
{[0.0569]}\end{array}$ & $\begin{array}{c}-0.1613^{* * *} \\
{[0.0598]}\end{array}$ \\
\hline $\begin{array}{l}\text { Interbank market share } \\
\qquad(\text { money centre banks) }\end{array}$ & $\begin{array}{c}0.2703 \\
{[0.2099]}\end{array}$ & $\begin{array}{c}0.117 \\
{[0.1679]}\end{array}$ & $\begin{array}{c}0.0489 \\
{[0.2108]}\end{array}$ & $\begin{array}{l}-0.0443 \\
{[0.3890]}\end{array}$ & $\begin{array}{c}0.0831 \\
{[0.1786]}\end{array}$ & $\begin{array}{c}0.0278 \\
{[0.2126]}\end{array}$ \\
\hline Government claims/assets & $\begin{array}{c}0.0231 \\
{[0.0159]}\end{array}$ & $\begin{array}{c}0.0344^{* * * *} \\
{[0.0132]}\end{array}$ & $\begin{array}{l}0.0270^{*} \\
{[0.0140]}\end{array}$ & $\begin{array}{c}0.0318 \\
{[0.0205]}\end{array}$ & $\begin{array}{c}0.0317^{* * * *} \\
{[0.0119]}\end{array}$ & $\begin{array}{c}0.0264^{* *} \\
{[0.0127]}\end{array}$ \\
\hline Government portfolio share & $\begin{array}{l}-0.3357 \\
{[0.4349]}\end{array}$ & $\begin{array}{l}-0.1351 \\
{[0.2721]}\end{array}$ & $\begin{array}{l}-0.1307 \\
{[0.2584]}\end{array}$ & $\begin{array}{r}-1.5549^{*} \\
{[0.9145]}\end{array}$ & $\begin{array}{l}-0.2063 \\
{[0.3294]}\end{array}$ & $\begin{array}{l}-0.2078 \\
{[0.3333]}\end{array}$ \\
\hline
\end{tabular}




\begin{tabular}{|c|c|c|c|c|c|c|}
\hline \multicolumn{7}{|l|}{ TABLE 5A } \\
\hline & $\begin{array}{c}\text { (1) } \\
\text { nbreach }\end{array}$ & $\begin{array}{c}\text { (2) } \\
\text { sbreach }\end{array}$ & $\begin{array}{c}\text { (3) } \\
\text { vbreach }\end{array}$ & $\begin{array}{c}\text { (4) } \\
\text { nbreach }\end{array}$ & $\begin{array}{c}(5) \\
\text { sbreach }\end{array}$ & $\begin{array}{c}(6) \\
\text { vbreach }\end{array}$ \\
\hline & \multicolumn{3}{|c|}{ Merger Excluded } & \multicolumn{3}{|c|}{ Merger Included } \\
\hline \multicolumn{7}{|c|}{ Compliance with Regulatory Standards } \\
\hline Non-reported scores & $\begin{array}{c}1.7734^{* * *} \\
{[0.2219]}\end{array}$ & $\begin{array}{c}1.5782^{* * *} \\
{[0.2077]}\end{array}$ & $\begin{array}{c}1.6133^{* * *} \\
{[0.2104]}\end{array}$ & $\begin{array}{c}1.5015^{* * *} \\
{[0.2506]}\end{array}$ & $\begin{array}{c}1.3474 * * * \\
{[0.1976]}\end{array}$ & $\begin{array}{c}1.3596^{* * *} \\
{[0.2004]}\end{array}$ \\
\hline Capital adequacy ratio (N1) & $\begin{array}{l}-0.0253 \\
{[0.0688]}\end{array}$ & $\begin{array}{l}-0.0824 \\
{[0.0506]}\end{array}$ & $\begin{array}{c}0.0219 \\
{[0.0164]}\end{array}$ & $\begin{array}{c}0.0394 \\
{[0.0964]}\end{array}$ & $\begin{array}{l}-0.0878^{*} \\
{[0.0485]}\end{array}$ & $\begin{array}{c}0.018 \\
{[0.0165]}\end{array}$ \\
\hline Quick liquidity ratio (N2) & $\begin{array}{c}0.4368^{* * *} \\
{[0.1137]}\end{array}$ & $\begin{array}{c}0.3406 * * * \\
{[0.0755]}\end{array}$ & $\begin{array}{c}0.1173^{* * *} \\
{[0.0207]}\end{array}$ & $\begin{array}{c}0.9817^{* * *} \\
{[0.1910]}\end{array}$ & $\begin{array}{c}0.3270 * * * \\
{[0.0741]}\end{array}$ & $\begin{array}{c}0.1098^{* * *} \\
{[0.0212]}\end{array}$ \\
\hline Current liquidity ratio (N3) & $\begin{array}{c}0.2160^{* *} \\
{[0.1030]}\end{array}$ & $\begin{array}{c}-0.5292^{* *} \\
{[0.2121]}\end{array}$ & $\begin{array}{c}-0.1137^{* * *} * \\
{[0.0362]}\end{array}$ & $\begin{array}{c}0.4314^{* * *} \\
{[0.1384]}\end{array}$ & $\begin{array}{c}-0.5307^{* *} \\
{[0.2069]}\end{array}$ & $\begin{array}{c}-0.1101^{* * *} \\
{[0.0348]}\end{array}$ \\
\hline Long-term liquidity ratio (N4) & $\begin{array}{r}-0.4393^{*} \\
{[0.2297]}\end{array}$ & $\begin{array}{c}0.7402 \\
{[0.5946]}\end{array}$ & $\begin{array}{c}0.1457 \\
{[0.2991]}\end{array}$ & $\begin{array}{c}-0.8064^{* *} \\
{[0.3297]}\end{array}$ & $\begin{array}{c}0.8383 \\
{[0.5734]}\end{array}$ & $\begin{array}{c}0.0741 \\
{[0.2910]}\end{array}$ \\
\hline General liquidity ratio (N5) & $\begin{array}{c}-0.2391 * * * \\
{[0.0886]}\end{array}$ & $\begin{array}{c}2.0223^{* * *} \\
{[0.5491]}\end{array}$ & $\begin{array}{l}0.1420^{*} \\
{[0.0744]}\end{array}$ & $\begin{array}{c}-0.5500 * * * \\
{[0.1506]}\end{array}$ & $\begin{array}{c}1.8343^{* * *} \\
{[0.5287]}\end{array}$ & $\begin{array}{l}0.1232^{*} \\
{[0.0704]}\end{array}$ \\
\hline $\begin{array}{l}\text { Large-risks- } \\
\qquad \text { to-capital ratio (N7) }\end{array}$ & $\begin{array}{c}0.0605 \\
{[0.3349]}\end{array}$ & $\begin{array}{l}2.2841 \\
{[2.3742]}\end{array}$ & $\begin{array}{l}2.5463 \\
{[1.9380]}\end{array}$ & $\begin{array}{c}0.1014 \\
{[0.3757]}\end{array}$ & $\begin{array}{l}2.1966 \\
{[2.3479]}\end{array}$ & $\begin{array}{c}2.4205 \\
{[1.8426]}\end{array}$ \\
\hline $\begin{array}{l}\text { Owner-related-credit-risks- } \\
\text { to-capital ratio (N9.1) }\end{array}$ & $\begin{array}{c}0.2722 \\
{[0.1794]}\end{array}$ & $\begin{array}{c}0.0796 \\
{[0.4097]}\end{array}$ & $\begin{array}{c}0.1778 \\
{[0.1963]}\end{array}$ & $\begin{array}{c}0.6665^{* * *} \\
{[0.2194]}\end{array}$ & $\begin{array}{l}{[-0.0498} \\
{[0.3717]}\end{array}$ & $\begin{array}{c}0.1088 \\
{[0.1833]}\end{array}$ \\
\hline Insider-related-credit-risks- & 0.193 & -0.0577 & 0.0023 & $0.4861^{* *}$ & -0.1303 & -0.0122 \\
\hline to-capital ratio $(\mathrm{N} 10.1)$ & {$[0.1894]$} & {$[0.2778]$} & {$[0.0736]$} & {$[0.2362]$} & {$[0.2873]$} & {$[0.0782]$} \\
\hline $\begin{array}{l}\text { Individuals' deposits- } \\
\text { to-capital ratio (N11) }\end{array}$ & $\begin{array}{l}-0.0106 \\
{[0.0561]}\end{array}$ & $\begin{array}{l}-0.2558 \\
{[0.2028]}\end{array}$ & $\begin{array}{l}-0.0231 \\
{[0.0358]}\end{array}$ & $\begin{array}{l}-0.0227 \\
{[0.0601]}\end{array}$ & $\begin{array}{l}-0.1877 \\
{[0.1806]}\end{array}$ & $\begin{array}{l}-0.0046 \\
{[0.0276]}\end{array}$ \\
\hline Investment-to-shares- & $0.3902^{* *}$ & 0.3268 & 0.1757 & $0.7198^{* * *}$ & 0.1757 & 0.113 \\
\hline to-capital ratio $(\mathrm{N} 12)$ & {$[0.1580]$} & {$[0.3409]$} & {$[0.1278]$} & {$[0.2403]$} & {$[0.3536]$} & {$[0.1281]$} \\
\hline $\begin{array}{l}\text { Issued-promissory-notes- } \\
\text { to-capital ratio (N13) }\end{array}$ & $\begin{array}{c}0.0052 \\
{[0.1235]}\end{array}$ & $\begin{array}{c}0.2787 \\
{[0.2424]}\end{array}$ & $\begin{array}{l}-0.0109 \\
{[0.0883]}\end{array}$ & $\begin{array}{l}-0.0031 \\
{[0.1045]}\end{array}$ & $\begin{array}{c}0.2943 \\
{[0.2229]}\end{array}$ & $\begin{array}{c}0.0719 \\
{[0.0518]}\end{array}$ \\
\hline Observations & 19728 & 19381 & 19168 & 20048 & 19694 & 19475 \\
\hline Number of banks & 1393 & 1376 & 1364 & 1432 & 1413 & 1401 \\
\hline Log Likelihood & -635.91 & -602.89 & -601.29 & -819.86 & -779.52 & -776.8 \\
\hline Wald chi 2 & 220.48 & 296.42 & 268.87 & 175.09 & 299.17 & 269.72 \\
\hline
\end{tabular}

Note: The breach variables in the regression equations are: (1) and (4) the number of breaches (nbreach), (2) and (5) the severity of breaches (sbreach) and (3) and (6) the volume of breaches (vbreach). The dependent variable is a dummy variable, license withdrawal, which equals one in the quarter when a bank's license was revoked and zero otherwise. Moscow is a dummy variable which equals one if the bank is located in Moscow and zero otherwise. The Herfindahl index is an average over time. All other variables are time-varying. Table 1 provides a more detailed description of all variables. The logit estimations are performed under the $\mathrm{RE}$ assumption. Robust standard errors are given in brackets. ${ }^{*},{ }^{* *}$ and ${ }^{* * *}$ indicate significance levels of 10,5 and 1 percent respectively. 


\begin{tabular}{|c|c|c|c|c|c|c|}
\hline & $\begin{array}{c}(1 \mathrm{a}) \\
\alpha=.3\end{array}$ & $\begin{array}{c}\text { dnbreach } \\
\text { (1b) } \\
\alpha=.5\end{array}$ & $\begin{array}{c}(1 \mathrm{c}) \\
\alpha=.7\end{array}$ & $\begin{array}{c}(2 \mathrm{a}) \\
\alpha=.3\end{array}$ & $\begin{array}{c}\text { dsbreach } \\
(2 \mathrm{~b}) \\
\alpha=.5\end{array}$ & $\begin{array}{c}(2 \mathrm{c}) \\
\alpha=.7\end{array}$ \\
\hline Constant & $\begin{array}{c}-4.6578^{* * *} \\
{[0.9064]}\end{array}$ & $\begin{array}{c}-4.3521^{* * *} \\
{[0.7788]}\end{array}$ & $\begin{array}{c}-4.0474^{* * *} \\
{[0.7159]}\end{array}$ & $\begin{array}{c}-3.4314^{* * *} \\
{[0.5268]}\end{array}$ & $\begin{array}{c}-3.3687^{* * *} \\
{[0.6102]}\end{array}$ & $\begin{array}{c}-3.1164^{* * *} \\
{[0.5360]}\end{array}$ \\
\hline Deflator & $\begin{array}{l}-0.0636 \\
{[0.0750]}\end{array}$ & $\begin{array}{l}-0.0353 \\
{[0.0654]}\end{array}$ & $\begin{array}{l}-0.0115 \\
{[0.0606]}\end{array}$ & $\begin{array}{l}-0.0536 \\
{[0.0501]}\end{array}$ & $\begin{array}{c}-0.1107^{*} \\
{[0.0618]}\end{array}$ & $\begin{array}{l}-0.0679 \\
{[0.0507]}\end{array}$ \\
\hline Moscow Dummy & $\begin{array}{c}0.3821 \\
{[0.4946]}\end{array}$ & $\begin{array}{c}0.3412 \\
{[0.4422]}\end{array}$ & $\begin{array}{c}0.285 \\
{[0.4065]}\end{array}$ & $\begin{array}{c}0.5047 \\
{[0.3204]}\end{array}$ & $\begin{array}{c}0.452 \\
{[0.3509]}\end{array}$ & $\begin{array}{c}0.425 \\
{[0.3279]}\end{array}$ \\
\hline \multicolumn{7}{|l|}{ Economic Variables } \\
\hline Return on assets & $\begin{array}{c}-0.0103^{*} \\
{[0.0055]}\end{array}$ & $\begin{array}{c}-0.0093^{*} \\
{[0.0049]}\end{array}$ & $\begin{array}{c}-0.0083^{*} \\
{[0.0047]}\end{array}$ & $\begin{array}{c}-0.0161^{* * *} \\
{[0.0058]}\end{array}$ & $\begin{array}{c}-0.0115^{*} \\
{[0.0061]}\end{array}$ & $\begin{array}{c}-0.0107^{*} \\
{[0.0056]}\end{array}$ \\
\hline Cost/assets & $\begin{array}{c}0.1602^{* * *} \\
{[0.0391]}\end{array}$ & $\begin{array}{c}0.1390^{* * *} \\
{[0.0342]}\end{array}$ & $\begin{array}{c}0.1247^{* * *} \\
{[0.0319]}\end{array}$ & $\begin{array}{c}0.1175^{* * *} \\
{[0.0230]}\end{array}$ & $\begin{array}{c}0.1207 * * * \\
{[0.0267]}\end{array}$ & $\begin{array}{c}0.1084^{* * *} \\
{[0.0243]}\end{array}$ \\
\hline Interbank liabilities/liabilities & $\begin{array}{c}-0.0171^{* *} \\
{[0.0068]}\end{array}$ & $\begin{array}{c}-0.0155^{* *} \\
{[0.0064]}\end{array}$ & $\begin{array}{c}-0.0141^{* *} \\
{[0.0060]}\end{array}$ & $\begin{array}{l}-0.0032 \\
{[0.0047]}\end{array}$ & $\begin{array}{l}-0.0043 \\
{[0.0050]}\end{array}$ & $\begin{array}{l}-0.0058 \\
{[0.0046]}\end{array}$ \\
\hline Regional market share(assets) & $\begin{array}{l}-0.0035 \\
{[0.0223]}\end{array}$ & $\begin{array}{l}-0.0002 \\
{[0.0197]}\end{array}$ & $\begin{array}{c}0.0032 \\
{[0.0183]}\end{array}$ & $\begin{array}{c}0.0049 \\
{[0.0150]}\end{array}$ & $\begin{array}{c}0.0027 \\
{[0.0153]}\end{array}$ & $\begin{array}{c}0.0066 \\
{[0.0139]}\end{array}$ \\
\hline Non performing loans/loans & $\begin{array}{c}0.0223^{* * *} \\
{[0.0060]}\end{array}$ & $\begin{array}{c}0.0178^{* * *} \\
{[0.0055]}\end{array}$ & $\begin{array}{c}0.0157^{* * *} * \\
{[0.0052]}\end{array}$ & $\begin{array}{c}0.0147^{* * *} \\
{[0.0040]}\end{array}$ & $\begin{array}{c}0.0165^{* * *} \\
{[0.0050]}\end{array}$ & $\begin{array}{c}0.0126^{* * *} \\
{[0.0042]}\end{array}$ \\
\hline Reserves/assets & $\begin{array}{c}-0.1093^{* * *} \\
{[0.0198]}\end{array}$ & $\begin{array}{c}-0.0972^{* * *} \\
{[0.0187]}\end{array}$ & $\begin{array}{c}-0.0906^{* * *} \\
{[0.0177]}\end{array}$ & $\begin{array}{c}-0.1063^{* * *} * \\
{[0.0172]}\end{array}$ & $\begin{array}{c}-0.1076^{* * *} \\
{[0.0178]}\end{array}$ & $\begin{array}{c}-0.1103^{* * *} \\
{[0.0177]}\end{array}$ \\
\hline Tacit CBR Objectives & & & & & & \\
\hline Regional Herfindahl (assets) & $\begin{array}{c}-0.0011^{* * *} \\
{[0.0003]}\end{array}$ & $\begin{array}{c}-0.0010^{* * *} \\
{[0.0002]}\end{array}$ & $\begin{array}{c}-0.0009^{* * *} \\
{[0.0002]}\end{array}$ & $\begin{array}{c}-0.0006^{* * *} \\
{[0.0002]}\end{array}$ & $\begin{array}{c}-0.0006^{* * *} \\
{[0.0002]}\end{array}$ & $\begin{array}{c}-0.0006^{* * *} \\
{[0.0002]}\end{array}$ \\
\hline Size (log assets) & $\begin{array}{c}-0.2573^{* * *} * \\
{[0.0886]}\end{array}$ & $\begin{array}{c}-0.2796^{* * *} \\
{[0.0833]}\end{array}$ & $\begin{array}{c}-0.2912^{* * *} \\
{[0.0787]}\end{array}$ & $\begin{array}{c}-0.1659^{* * *} * \\
{[0.0591]}\end{array}$ & $\begin{array}{c}-0.2116^{* * *} \\
{[0.0667]}\end{array}$ & $\begin{array}{c}-0.2136^{* * *} \\
{[0.0598]}\end{array}$ \\
\hline $\begin{array}{l}\text { Interbank market share } \\
\text { (money centre banks) }\end{array}$ & $\begin{array}{c}0.2456 \\
{[0.3069]}\end{array}$ & $\begin{array}{c}0.1417 \\
{[0.3520]}\end{array}$ & $\begin{array}{c}0.1018 \\
{[0.3404]}\end{array}$ & $\begin{array}{c}0.1429 \\
{[0.1518]}\end{array}$ & $\begin{array}{c}0.1774 \\
{[0.1708]}\end{array}$ & $\begin{array}{c}0.1104 \\
{[0.1892]}\end{array}$ \\
\hline Government claims/assets & $\begin{array}{c}0.0178 \\
{[0.0173]}\end{array}$ & $\begin{array}{c}0.0146 \\
{[0.0163]}\end{array}$ & $\begin{array}{c}0.0121 \\
{[0.0151]}\end{array}$ & $\begin{array}{c}0.0359^{* * *} \\
{[0.0125]}\end{array}$ & $\begin{array}{c}0.0352^{* * *} \\
{[0.0137]}\end{array}$ & $\begin{array}{c}0.0336^{* * *} \\
{[0.0122]}\end{array}$ \\
\hline Government portfolio share & $\begin{array}{l}-0.6673 \\
{[0.7189]}\end{array}$ & $\begin{array}{l}-0.5481 \\
{[0.6301]}\end{array}$ & $\begin{array}{c}-0.445 \\
{[0.5674]}\end{array}$ & $\begin{array}{l}-0.1332 \\
{[0.2929]}\end{array}$ & $\begin{array}{l}-0.1438 \\
{[0.3111]}\end{array}$ & $\begin{array}{l}-0.0926 \\
{[0.2415]}\end{array}$ \\
\hline
\end{tabular}




\begin{tabular}{|c|c|c|c|c|c|c|}
\hline \multicolumn{7}{|l|}{ TABLE 5B } \\
\hline & \multicolumn{3}{|c|}{ dnbreach } & \multicolumn{3}{|c|}{ dsbreach } \\
\hline & $(1 \mathrm{a})$ & (1b) & $(1 \mathrm{c})$ & $(2 \mathrm{a})$ & $(2 \mathrm{~b})$ & $(2 \mathrm{c})$ \\
\hline & $\alpha=.3$ & $\alpha=.5$ & $\alpha=.7$ & $\alpha=.3$ & $\alpha=.5$ & $\alpha=.7$ \\
\hline \multicolumn{7}{|c|}{ Compliance with Regulatory Standards } \\
\hline \multirow[t]{2}{*}{ Non-reported scores } & $1.8602^{* * *}$ & $1.7681^{* * *}$ & $1.7048^{* * *}$ & $1.5326^{* * *}$ & $1.5002^{* * *}$ & $1.4089^{* * *}$ \\
\hline & {$[0.2440]$} & {$[0.2372]$} & [0.2308] & {$[0.2130]$} & {$[0.2247]$} & [0.2188] \\
\hline \multirow[t]{2}{*}{ Capital adequacy ratio (N1) } & 0.0405 & $0.0926^{* *}$ & $0.1151^{* * *}$ & -0.0477 & -0.0143 & $0.1852^{*}$ \\
\hline & {$[0.0570]$} & [0.0434] & {$[0.0365]$} & [0.0689] & {$[0.0688]$} & {$[0.0978]$} \\
\hline \multirow[t]{2}{*}{ Quick liquidity ratio (N2) } & $0.3829^{* * *}$ & $0.2850^{* * *}$ & $0.2272^{* * *}$ & $0.2064^{* * *}$ & $0.1426^{* *}$ & 0.0056 \\
\hline & {$[0.0730]$} & [0.0477] & {$[0.0370]$} & {$[0.0658]$} & {$[0.0673]$} & [0.0708] \\
\hline \multirow[t]{2}{*}{ Current liquidity ratio (N3) } & $0.1863^{* *}$ & $0.1208^{* *}$ & $0.0889 * *$ & -0.5346 & 0.5276 & $1.5077^{*} * *$ \\
\hline & {$[0.0734]$} & {$[0.0516]$} & {$[0.0413]$} & {$[0.3405]$} & {$[0.4386]$} & {$[0.5664]$} \\
\hline \multirow[t]{2}{*}{ Long-term liquidity ratio (N4) } & -0.1946 & -0.0832 & -0.0444 & 0.5298 & 0.8268 & $2.5782^{* * *}$ \\
\hline & {$[0.1534]$} & {$[0.0979]$} & {$[0.0753]$} & {$[0.8485]$} & [0.9808] & [0.9392] \\
\hline \multirow[t]{2}{*}{ General liquidity ratio (N5) } & -0.0251 & 0.0263 & 0.0416 & $2.6931^{* * *}$ & $1.7517^{* * *}$ & 0.67 \\
\hline & {$[0.0744]$} & {$[0.0517]$} & {$[0.0404]$} & [0.4980] & {$[0.5036]$} & [0.5093] \\
\hline Large-risks- & 0.2082 & 0.1406 & 0.0909 & -0.292 & 4.6287 & $5.4788^{*}$ \\
\hline to-capital ratio $(\mathrm{N} 7)$ & {$[0.1325]$} & {$[0.0869]$} & {$[0.0652]$} & {$[2.5027]$} & {$[3.1311]$} & [3.0403] \\
\hline Owner-related-credit-risks- & $0.3313^{*}$ & 0.1867 & 0.1311 & $1.1493^{* * *}$ & 0.7023 & $0.9933^{*}$ \\
\hline to-capital ratio $(\mathrm{N} 9.1)$ & {$[0.1790]$} & {$[0.1302]$} & {$[0.1032]$} & [0.4413] & {$[0.5689]$} & {$[0.5271]$} \\
\hline Insider-related-credit-risks- & $0.3147 * * *$ & $0.1928^{* *}$ & 0.1167 & 0.0009 & 0.0787 & $0.4321 * *$ \\
\hline to-capital ratio $(\mathrm{N} 10.1)$ & [0.1179] & {$[0.0945]$} & {$[0.0826]$} & {$[0.0880]$} & {$[0.1644]$} & {$[0.2167]$} \\
\hline Individuals' deposits- & -0.0542 & -0.0578 & -0.0551 & -0.2562 & -0.2294 & -0.3398 \\
\hline to-capital ratio $(\mathrm{N} 11)$ & {$[0.0627]$} & {$[0.0546]$} & {$[0.0479]$} & {$[0.2312]$} & {$[0.2669]$} & {$[0.2641]$} \\
\hline Investment-to-shares- & 0.2175 & 0.1043 & 0.0514 & 0.0387 & -0.6422 & 0.015 \\
\hline to-capital ratio (N12) & {$[0.1432]$} & {$[0.1138]$} & {$[0.0893]$} & {$[0.7810]$} & {$[1.4594]$} & [1.1001] \\
\hline Issued-promissory-notes- & 0.0203 & 0.0353 & 0.0357 & -0.0199 & -0.3255 & -0.405 \\
\hline to-capital ratio (N13) & {$[0.0999]$} & {$[0.0711]$} & {$[0.0571]$} & {$[0.3569]$} & {$[0.5980]$} & [0.4963] \\
\hline Observations & 19481 & 19728 & 19728 & 19445 & 19484 & 19507 \\
\hline Number of banks & 1393 & 1393 & 1393 & 1382 & 1382 & 1385 \\
\hline Log Likelihood & -572.84 & -553.12 & -545.77 & -560.38 & -546.38 & -547.22 \\
\hline Wald chi2 & 166.27 & 193.34 & 212.38 & 413.15 & 243.15 & 435.23 \\
\hline
\end{tabular}

Note: The breach variables in the regression equation are: (1) discounted number of breaches assuming exponential smoothing: (1a) dnbreach $(\alpha=0.3)$, (1b) dnbreach $(\alpha=0.5),(1 \mathrm{c})$ dnbreach $(\alpha=0.7),(2)$ discounted severity of breaches assuming exponential smoothing: (2a) dsbreach $(\alpha=0.3),(2 \mathrm{~b})$ dsbreach $(\alpha=0.5),(2 \mathrm{c})$ dsbreach $(\alpha=0.7)$. The dependent variable is a dummy variable, license withdrawal, which equals one in the quarter when a bank's license was revoked and zero otherwise. Moscow is a dummy variable which equals one if the bank is located in Moscow and zero otherwise. The Herfindahl index is an average over time. All other variables are time-varying. Table 1 provides a more detailed description of all variables. The logit estimations are performed under the RE assumption. Robust standard errors are given in brackets. ${ }^{*}, * *$ and ${ }^{* * *}$ indicate significance levels of 10,5 and 1 percent respectively. 


\section{TABLE 6}

Model Selection for the Survival Model: Akaike Information Criterion

\begin{tabular}{|c|c|c|c|c|c|c|}
\hline & & & Exponential & Weibull & Gompertz & Loglogistic \\
\hline \multirow{3}{*}{ dnbreach } & (1a) & $\alpha=.3$ & 182.39 & 181.09 & 182.38 & 146.43 \\
\hline & (1b) & $\alpha=.5$ & 144.48 & 144.91 & 145.86 & 119.01 \\
\hline & (1c) & $\alpha=.7$ & 127.66 & 128.69 & 129.42 & 108.80 \\
\hline \multirow{3}{*}{ dsbreach } & $(2 \mathrm{a})$ & $\alpha=.3$ & 302.75 & 299.15 & 300.01 & 197.85 \\
\hline & $(2 \mathrm{~b})$ & $\alpha=.5$ & 291.26 & 288.56 & 289.30 & 163.61 \\
\hline & $(2 \mathrm{c})$ & $\alpha=.7$ & 270.24 & 268.13 & 268.87 & 127.38 \\
\hline
\end{tabular}

Note: The breach variables in the regression equation are: (1) discounted number of breaches assuming exponential smoothing: (1a) dnbreach $(\alpha=0.3)$, (1b) dnbreach $(\alpha=0.5),(1 \mathrm{c})$ dnbreach $(\alpha=0.7),(2)$ discounted severity of breaches assuming exponential smoothing: (2a) dsbreach $(\alpha=0.3),(2 \mathrm{~b})$ dsbreach $(\alpha=0.5),(2 \mathrm{c})$ dsbreach $(\alpha=0.7)$. We choose the parameterization which minimizes the AIC (bold). 


\begin{tabular}{|c|c|c|c|c|c|c|}
\hline & $\begin{array}{c}(1 \mathrm{a}) \\
\alpha=.3\end{array}$ & $\begin{array}{c}\text { dnbreach } \\
\quad(1 \mathrm{~b}) \\
\alpha=.5\end{array}$ & $\begin{array}{c}(1 \mathrm{c}) \\
\alpha=.7\end{array}$ & $\begin{array}{c}(2 \mathrm{a}) \\
\alpha=.3\end{array}$ & $\begin{array}{c}\text { dsbreach } \\
(2 \mathrm{~b}) \\
\alpha=.5\end{array}$ & $\begin{array}{c}(2 \mathrm{c}) \\
\alpha=.7\end{array}$ \\
\hline \multirow[t]{2}{*}{ Constant } & $3.8072^{* * *}$ & $3.7392^{* * *}$ & $3.7302^{* * *}$ & $4.1602^{* * *}$ & $3.9582^{* * *}$ & $3.9480^{* * *}$ \\
\hline & [0.2094] & [0.1938] & [0.1893] & {$[0.2922]$} & {$[0.2725]$} & [0.2827] \\
\hline \multirow[t]{2}{*}{ Deflator } & -0.0283 & -0.0277 & $-0.0303^{*}$ & 0.0211 & 0.0251 & 0.0389 \\
\hline & {$[0.0185]$} & {$[0.0170]$} & {$[0.0161]$} & {$[0.0307]$} & [0.0302] & [0.0299] \\
\hline Moscow Dummy & -0.1996 & -0.1653 & -0.1773 & $-0.4914^{* *}$ & $-0.4179^{* *}$ & $-0.4744^{* *}$ \\
\hline Economic Variables & {$[0.1311]$} & {$[0.1233]$} & {$[0.1188]$} & [0.1951] & {$[0.1773]$} & [0.1863] \\
\hline \multirow{2}{*}{ Return on assets } & $0.0035^{* *}$ & 0.002 & 0.0015 & 0.0014 & 0.0018 & 0.0007 \\
\hline & {$[0.0017]$} & {$[0.0017]$} & {$[0.0016]$} & {$[0.0025]$} & {$[0.0070]$} & {$[0.0025]$} \\
\hline \multirow[t]{2}{*}{ Cost/assets } & $-0.0260 * *$ & $-0.0238^{* *}$ & $-0.0216^{* *}$ & $-0.0510^{* *}$ & $-0.0452^{* *}$ & $-0.0412^{* * *}$ \\
\hline & [0.0112] & {$[0.0100]$} & {$[0.0096]$} & [0.0198] & {$[0.0184]$} & {$[0.0144]$} \\
\hline \multirow[t]{2}{*}{ Interbank liabilities/liabilities } & $0.0058^{* *}$ & $0.0052^{* *}$ & $0.0046^{* *}$ & 0.0053 & $0.0053^{*}$ & $0.0054^{*}$ \\
\hline & {$[0.0025]$} & {$[0.0023]$} & {$[0.0022]$} & {$[0.0032]$} & {$[0.0030]$} & [0.0029] \\
\hline \multirow[t]{2}{*}{ Regional market share (assets) } & -0.0041 & -0.0021 & -0.0015 & 0.0109 & 0.0027 & 0.002 \\
\hline & {$[0.0064]$} & {$[0.0068]$} & {$[0.0062]$} & {$[0.0133]$} & {$[0.0110]$} & [0.0100] \\
\hline \multirow[t]{2}{*}{ Non performing loans/loans } & -0.0029 & -0.0026 & -0.0023 & -0.0043 & -0.002 & -0.0027 \\
\hline & {$[0.0024]$} & {$[0.0021]$} & {$[0.0020]$} & {$[0.0033]$} & {$[0.0030]$} & [0.0029] \\
\hline Reserves/assets & $0.0338 * * *$ & $0.0298^{* * *}$ & $0.0266^{* * *}$ & $0.0318^{* * *}$ & $0.0313^{* * *}$ & $0.0313^{* * *}$ \\
\hline Tacit CBR Objectives & {$[0.0067]$} & {$[0.0063]$} & {$[0.0059]$} & {$[0.0078]$} & {$[0.0082]$} & [0.0074] \\
\hline \multirow[t]{2}{*}{ Regional Herfindahl (assets) } & $0.0002 * * *$ & $0.0002^{* * *}$ & $0.0002^{* * *}$ & 0.0001 & 0.0001 & 0.0001 \\
\hline & {$[0.0001]$} & {$[0.0001]$} & {$[0.0001]$} & {$[0.0001]$} & {$[0.0001]$} & [0.0001] \\
\hline \multirow[t]{2}{*}{ Size (log assets) } & $0.0653^{* * *}$ & $0.0700^{* * *}$ & $0.0780 * * *$ & $0.0825^{* *}$ & $0.0871^{* * *}$ & $0.0883^{* * *}$ \\
\hline & {$[0.0232]$} & {$[0.0222]$} & [0.0219] & {$[0.0323]$} & {$[0.0314]$} & {$[0.0284]$} \\
\hline Interbank market share & -0.0225 & -0.016 & -0.013 & -0.0506 & -0.037 & -0.0025 \\
\hline (money centre banks) & {$[0.1094]$} & {$[0.1276]$} & {$[0.1290]$} & {$[0.1099]$} & {$[0.1270]$} & {$[0.1770]$} \\
\hline \multirow[t]{2}{*}{ Government claims/assets } & -0.006 & -0.0013 & 0.0009 & -0.0133 & $-0.0158^{*}$ & -0.0131 \\
\hline & [0.0093] & {$[0.0079]$} & {$[0.0059]$} & {$[0.0107]$} & {$[0.0093]$} & {$[0.0108]$} \\
\hline \multirow[t]{2}{*}{ Government portfolio share } & 0.1537 & 0.2388 & 0.2166 & 0.8542 & 0.6535 & 0.7296 \\
\hline & {$[0.1929]$} & {$[0.3193]$} & {$[0.2915]$} & {$[0.6338]$} & {$[1.5134]$} & [0.6081] \\
\hline
\end{tabular}




\begin{tabular}{cccccc} 
(1a) & dnbreach & \multicolumn{3}{c}{ dsbreach } \\
$\alpha=.3$ & $(1 \mathrm{~b})$ & $(1 \mathrm{c})$ & $(2 \mathrm{a})$ & $(2 \mathrm{~b})$ & $(2 \mathrm{c})$ \\
& $\alpha=.5$ & $\alpha=.7$ & $\alpha=.3$ & $\alpha=.5$ & $\alpha=.7$
\end{tabular}

\begin{tabular}{|c|c|c|c|c|c|c|}
\hline \multicolumn{7}{|c|}{ Compliance with Regulatory Standards } \\
\hline \multirow[t]{2}{*}{ Non-reported scores } & $-0.6639 * * *$ & $-0.6443^{* * *}$ & $-0.6254^{* * *}$ & $-0.7727^{* * *}$ & $-0.7678^{* * *}$ & $-0.7460 * * *$ \\
\hline & [0.1023] & [0.0919] & {$[0.0889]$} & {$[0.1342]$} & {$[0.1158]$} & {$[0.1122]$} \\
\hline \multirow[t]{2}{*}{ Capital adequacy ratio (N1) } & -0.0297 & -0.0267 & $-0.0284^{*}$ & 0.2259 & -0.0784 & -0.3751 \\
\hline & {$[0.0272]$} & {$[0.0202]$} & {$[0.0170]$} & {$[0.1740]$} & {$[0.1330]$} & {$[0.3024]$} \\
\hline \multirow[t]{2}{*}{ Quick liquidity ratio (N2) } & $-0.1463^{* * *}$ & $-0.1005^{* * *}$ & $-0.0790 * * *$ & $-1.5551 * *$ & $-1.3822^{* * *}$ & $-1.2931^{* * *}$ \\
\hline & {$[0.0285]$} & {$[0.0200]$} & {$[0.0155]$} & {$[0.6215]$} & {$[0.3681]$} & {$[0.3240]$} \\
\hline \multirow[t]{2}{*}{ Current liquidity ratio (N3) } & $-0.0629 * *$ & $-0.0502 * * *$ & $-0.0421^{* * *}$ & $-4.0266 * * *$ & $-1.9672 * * *$ & $-1.2172^{* * *}$ \\
\hline & [0.0248] & {$[0.0179]$} & {$[0.0145]$} & {$[1.1415]$} & [0.6934] & [0.4609] \\
\hline \multirow[t]{2}{*}{ Long-term liquidity ratio (N4) } & $0.1499^{* *}$ & $0.1044^{* *}$ & $0.0737^{* *}$ & 2.7154 & $2.7784^{* *}$ & $1.8269^{*}$ \\
\hline & {$[0.0615]$} & {$[0.0422]$} & {$[0.0376]$} & {$[2.1230]$} & [1.2303] & [0.9578] \\
\hline \multirow[t]{2}{*}{ General liquidity ratio (N5) } & 0.0133 & 0.0011 & -0.0062 & 0.7897 & 0.2532 & -0.0164 \\
\hline & {$[0.0227]$} & {$[0.0165]$} & {$[0.0138]$} & {$[0.6787]$} & {$[0.4786]$} & [0.3608] \\
\hline \multirow{2}{*}{$\begin{array}{l}\text { Large-risks- } \\
\qquad \text { to-capital ratio (N7) }\end{array}$} & -0.0157 & -0.0104 & -0.0034 & -0.9381 & -2.8056 & $-4.2494^{* *}$ \\
\hline & {$[0.0424]$} & {$[0.0313]$} & {$[0.0270]$} & {$[2.3161]$} & {$[1.8444]$} & [1.8832] \\
\hline \multirow{2}{*}{$\begin{array}{l}\text { Owner-related-credit-risks- } \\
\text { to-capital ratio (N9.1) }\end{array}$} & -0.0523 & -0.0398 & -0.04 & 0.4501 & 0.2899 & 0.0642 \\
\hline & {$[0.0556]$} & {$[0.0415]$} & {$[0.0375]$} & {$[0.3709]$} & {$[0.4224]$} & [0.3412] \\
\hline \multirow{2}{*}{$\begin{array}{l}\text { Insider-related-credit-risks- } \\
\text { to-capital ratio }(\mathrm{N} 10.1)\end{array}$} & $-0.0921^{* * *}$ & $-0.0655^{* * *}$ & $-0.0548^{* * *}$ & -0.0012 & $-0.3293^{* * *}$ & $-0.3046^{* * *}$ \\
\hline & [0.0296] & {$[0.0233]$} & [0.0203] & {$[0.0230]$} & [0.1035] & [0.0916] \\
\hline \multirow{2}{*}{$\begin{array}{l}\text { Individuals' deposits- } \\
\text { to-capital ratio (N11) }\end{array}$} & 0.0305 & 0.0231 & 0.019 & $0.3554^{*}$ & $0.2845^{*}$ & $0.3701^{* *}$ \\
\hline & {$[0.0186]$} & {$[0.0151]$} & {$[0.0137]$} & {$[0.2013]$} & {$[0.1557]$} & [0.1739] \\
\hline \multirow{2}{*}{$\begin{array}{l}\text { Investment-to-shares- } \\
\text { to-capital ratio (N12) }\end{array}$} & $-0.0941^{*}$ & -0.0538 & -0.0392 & -0.5241 & -0.0729 & $-6.7723^{* * *}$ \\
\hline & {$[0.0565]$} & {$[0.0562]$} & {$[0.0629]$} & {$[0.4581]$} & {$[0.6801]$} & [1.8875] \\
\hline \multirow{2}{*}{$\begin{array}{l}\text { Issued-promissory-notes- } \\
\text { to-capital ratio (N13) }\end{array}$} & 0.0074 & -0.0089 & -0.0124 & 0.3182 & 0.3193 & 0.0271 \\
\hline & {$[0.0272]$} & {$[0.0190]$} & {$[0.0158]$} & {$[0.2411]$} & [0.3699] & [0.2705] \\
\hline Observations & 19481 & 19728 & 19728 & 19445 & 19484 & 19507 \\
\hline Number of banks & 1393 & 1393 & 1393 & 1382 & 1382 & 1385 \\
\hline Log Likelihood & -45.22 & -31.5 & -26.4 & -70.92 & -53.8 & -35.69 \\
\hline Wald chi2 & 642.84 & 673.97 & 684.18 & 531.66 & 557.49 & 602.4 \\
\hline No. of failures & 160 & 160 & 160 & 135 & 133 & 137 \\
\hline theta & 0.09 & $1.16 \mathrm{E}-09$ & $7.77 \mathrm{E}-10$ & 0.40 & $1.32 \mathrm{E}-10$ & $1.46 \mathrm{E}-10$ \\
\hline LR test heterogeneity & 0.22 & 0.00 & 0.00 & 1.63 & 0.00 & 0.00 \\
\hline Prob & 0.32 & 1 & 1 & 0.10 & 1 & 1 \\
\hline
\end{tabular}

Note: The breach variables in the regression equation are: (1) discounted number of breaches assuming exponential smoothing: (1a) dnbreach $(\alpha=0.3)$, (1b) dnbreach $(\alpha=0.5),(1 \mathrm{c})$ dnbreach $(\alpha=0.7),(2)$ discounted severity of breaches assuming exponential smoothing: (2a) dsbreach $(\alpha=0.3),(2 \mathrm{~b})$ dsbreach $(\alpha=0.5),(2 \mathrm{c})$ dsbreach $(\alpha=0.7)$. The dependent variable is the number of quarters between the issuance and revokal of a bank's license. Table 1 provides a detailed description of all explanatory variables. The functional form for the hazard ratio was chosen based on the Akaike information criterion of model selection. Detailed results for model selection are included in Table 6. All survival model estimations allow for bank-specific unobserved heterogeneity which is assumed to be inverse Gaussian distributed. Theta is an estimate of the variance of heterogeneity. The LR test for heterogeneity is a likelihood ratio test of the null hypothesis that this variance is zero. ${ }^{*}, * *$ and $* * *$ indicate significance levels of 10,5 and 1 percent respectively. 


\section{DAVIDSON INSTITUTE WORKING PAPER SERIES - Most Recent Papers}

The entire Working Paper Series may be downloaded free of charge at: www.wdi.bus.umich.edu

CURRENT AS OF 6/23/05

\begin{tabular}{|c|c|c|}
\hline Publication & Authors & Date \\
\hline $\begin{array}{l}\text { No. 778: Bank Supervision Russian style: Rules versus Enforcement } \\
\text { and Tacit Objectives }\end{array}$ & $\begin{array}{l}\text { Sophie Claeys, Gleb Lanine and } \\
\text { Koen Schoors }\end{array}$ & June 2005 \\
\hline No. 777: Labor Market Trends and Institutions in Belarus & $\begin{array}{l}\text { Zuzana Brixiova and Vera } \\
\text { Volchok }\end{array}$ & June 2005 \\
\hline $\begin{array}{l}\text { No. 776: Can Vietnam Achieve One of its Millennium Development } \\
\text { Goals? An analysis of schooling dropouts of children }\end{array}$ & $\begin{array}{l}\text { Vo Tri Thanh And Trinh Quang } \\
\text { Long }\end{array}$ & June 2005 \\
\hline $\begin{array}{l}\text { No. 775: Is The Link Between Reforms And Growth Spurious? A } \\
\text { Comment }\end{array}$ & Tomasz Mickiewicz & May 2005 \\
\hline $\begin{array}{l}\text { No. 774: The Risk Aversion of Banks in Emerging Credit markets: } \\
\text { Evidence from India }\end{array}$ & $\begin{array}{l}\text { Sumon Kumar Bhaumik and } \\
\text { Jenifer Piesse }\end{array}$ & May 2005 \\
\hline $\begin{array}{l}\text { No. 773: Organized Labor and Restructuring: Coal Mines in the Czech } \\
\text { Republic and Romania }\end{array}$ & $\begin{array}{l}\text { Jan Bruha, Delia Ionascu, and } \\
\text { Byeongju Jeong }\end{array}$ & May 2005 \\
\hline $\begin{array}{l}\text { No. 772: Is Political Risk Company-Specific? The Market Side of the } \\
\text { Yukos Affair }\end{array}$ & $\begin{array}{l}\text { Alexei Goriaev and Konstantin } \\
\text { Sonin }\end{array}$ & May 2005 \\
\hline $\begin{array}{l}\text { No. 771: Non-Linear Exchange Rate Dynamics in Target Zones: A } \\
\text { Bumpy Road Towards A Honeymoon }\end{array}$ & $\begin{array}{l}\text { Jesús Crespo-Cuaresma, Balázs } \\
\text { Égert, and Ronald MacDonald }\end{array}$ & May 2005 \\
\hline $\begin{array}{l}\text { No. 770: Equilibrium Exchange Rates in Southeastern Europe, Russia, } \\
\text { Ukraine and Turkey: Healthy or (Dutch) Diseased? }\end{array}$ & Balázs Égert & May 2005 \\
\hline $\begin{array}{l}\text { No. 769: Equilibrium Exchange Rates in Central and Eastern Europe: A } \\
\text { Meta-Regression Analysis }\end{array}$ & Balázs Égert and László Halpern & May 2005 \\
\hline $\begin{array}{l}\text { No. 768: Testing for inflation convergence between the Euro Zone } \\
\text { and its CEE partners }\end{array}$ & Imed Drine and Christophe Rault & Apr. 2005 \\
\hline $\begin{array}{l}\text { No. 767: Labor Mobility during Transition: Evidence from the Czech } \\
\text { Republic }\end{array}$ & Jan Fidrmuc & Apr. 2005 \\
\hline $\begin{array}{l}\text { No. 766: Formation of social capital in Central and Eastern Europe: } \\
\text { Understanding the gap vis-à-vis developed countries }\end{array}$ & Jan Fidrmuc and Klarita Gërxhani & Apr. 2005 \\
\hline $\begin{array}{l}\text { No. 765: Do Regional Integration Agreements Increase Business-Cycle } \\
\text { Convergence? Evidence From APEC and NAFTA }\end{array}$ & $\begin{array}{l}\text { Viviana Fernandez and Ali M. } \\
\text { Kutan }\end{array}$ & Apr. 2005 \\
\hline $\begin{array}{l}\text { No. 764: State Regulations, Job Search and Wage Bargaining: A Study } \\
\text { in the Economics of the Informal Sector }\end{array}$ & Maxim Bouev & Apr. 2005 \\
\hline $\begin{array}{l}\text { No. 763: The Feldstein-Horioka Puzzle Revisited: An “European- } \\
\text { Regional” Perspective }\end{array}$ & $\begin{array}{l}\text { Jérôme Hericourt and Mathilde } \\
\text { Maurel }\end{array}$ & Apr. 2005 \\
\hline $\begin{array}{l}\text { No. 762: Transatlantic Differences in Labour Markets Changes in Wage } \\
\text { and Non-Employment Structures in the 1980s and the 1990s }\end{array}$ & Patrick A. Puhani & Mar. 2005 \\
\hline $\begin{array}{l}\text { No. 761: Resolution, Recovery and Survival: The Evolution of Payment } \\
\text { Disputes in Post-Socialist Europe }\end{array}$ & William Pyle & Mar. 2005 \\
\hline $\begin{array}{l}\text { No. 760: Official Foreign Exchange Interventions in the Czech } \\
\text { Republic: Did They Matter? }\end{array}$ & Balázs Égert and Luboš Komárek & Mar. 2005 \\
\hline $\begin{array}{l}\text { No. 759: Assessing Market Expectations on Exchange Rates and } \\
\text { Inflation: A Pilot Forecasting System for Bulgaria }\end{array}$ & $\begin{array}{l}\text { Michael Berlemann, Kalina } \\
\text { Dimitrova, \& Nikolay Nenovsky }\end{array}$ & Mar. 2005 \\
\hline No. 758: Attitudes and Performance: An Analysis of Russian Workers & $\begin{array}{l}\text { Susan J. Linz and Anastasia } \\
\text { Semykina }\end{array}$ & Mar. 2005 \\
\hline $\begin{array}{l}\text { No. 757: Barter, Credit, and Welfare: A theoretical inquiry into the } \\
\text { barter phenomenon in Russia }\end{array}$ & José Noguera and Susan J. Linz & Mar. 2005 \\
\hline $\begin{array}{l}\text { No. 756: Sorting, Selection, and Transformation of the Return to } \\
\text { College Education In China }\end{array}$ & $\begin{array}{l}\text { Belton M. Fleisher, Haizheng Li, } \\
\text { Shi Li, and Xiaojun Wang }\end{array}$ & Mar. 2005 \\
\hline $\begin{array}{l}\text { No. 755: Foreign Exchange Interventions in Emerging Europe: } \\
\text { Should We Give a Damn? The Case of Croatia and Turkey }\end{array}$ & Balázs Égert and Maroje Lang & Mar. 2005 \\
\hline $\begin{array}{l}\text { No. 754: Targeting Relative Inflation Forecast as Monetary Policy } \\
\text { Framework for Adopting Euro }\end{array}$ & Lucjan T. Orlowski & Feb. 2005 \\
\hline $\begin{array}{l}\text { No. 753: Internet Entrepreneurship: Networks and Performance of } \\
\text { Internet Ventures In China }\end{array}$ & Bat Batjargal & Feb. 2005 \\
\hline $\begin{array}{l}\text { No. 752: Network Triads: Transitivity, Referral and Venture Capital } \\
\text { Decisions in China and Russia }\end{array}$ & Bat Batjargal & Feb. 2005 \\
\hline
\end{tabular}

